\title{
Testing for homologies in the axial skeleton of primitive echinoderms
}

\author{
Christopher R. C. Paul \\ School of Earth Sciences, University of Bristol, Bristol, UK 〈glcrcp@bris.ac.uk〉
}

\begin{abstract}
The extraxial axial theory is used to investigate homology of ambulacral and oral plating because it predicts terminal branching and terminal addition of plates in the axial skeleton, although exceptions to the former may occur in some Paleozoic echinoderms. The variety of morphological designs and anomalous individuals also provide tests of plate homology. Homology of ambulacra is generally accepted, with the hydropore and/or single gonopore in Carpenter's CD interray. In the 2-1-2 ambulacral pattern the unbranched ambulacrum is always in Carpenter's A ray. All ambulacral morphology requires just three instructions: 'grow,' 'branch,' and 'stop.' The range of variation in echinoderms with fewer than five ambulacra implies that both the 'branch' and 'stop' instructions acted independently in all five rays. Numbers of ambulacra may or may not correlate with numbers of orals. Two basic patterns of 'cystoid' oral plating occur; with a single radial (circum-oral, $\mathrm{CO}$ ) plate from each ambulacrum plus a sixth in the CD interray, and with all six interradial peri-oral (PO) plates, with two in the $\mathrm{CD}$ interambulacrum. Five 'orals' may involve loss of PO3 or PO6. Erect ambulacral structures are lost first in taphonomy and so poorly known. All ambulacral skeletal elements bear the same topological relationship to ambulacral soft tissues. Where branched ambulacra occur, the trunk or flooring plates are often modified first brachiolars or pinnulars. Both brachioles and pinnules may arise from facets developed on one or two flooring plates. Terminal addition of plates, spacing of brachioles/pinnules, and lack of musculature to open cover plates all suggest that 'cystoids' had extensions of the water vascular system in their ambulacra.
\end{abstract}

\section{Introduction}

There has been great progress in the study of fossil echinoderms recently, in terms of new taxonomic discoveries (e.g., helicocystids; Smith and Zamora, 2013), in teasing out evolutionary relationships (e.g., Sumrall and Wray, 2007; Sumrall and Waters, 2012; Zamora and Smith, 2012; Zamora and Rahman, 2015), and in theoretical concepts, such as the extraxial-axial theory (EAT; Mooi et al., 1994; David and Mooi, 1998) or universal elemental homology (UEH; Sumrall, 2008, 2010). Establishing homologies is an essential first step in phylogenetic analysis (e.g., Kammer et al., 2013). Over 50 years of research has taught me that to every generalization about fossil echinoderms there is an exception. Hyman (1955) was right that echinoderms are a group 'especially designed to puzzle the zoologist' (p. vi). Nevertheless, since science advances by testing hypotheses, these exceptions, whether teratological individuals or anomalous taxa, can often be used to test hypotheses about homology or phylogenetic relationships. Whether such exceptions 'prove the rule' or are the 'ugly fact that slays the beautiful hypothesis' or even just annoying anomalies that are hard to explain, they cannot be ignored. Choosing only examples that fit hypotheses does not test them. 'Anomalous' specimens test hypotheses of homology because they challenge us to decide which parts are homologous and which not and how the differences arose. This, in turn, may lead to further hypotheses of evolutionary relationships.
Here I confine discussion to axial skeletons of primitive echinoderms because the EAT hypothesizes that axial skeletal elements are only added and radial water vessels only branch terminally (though see the apparent exceptions to the second assumption posed by the Ordovician fossil sea urchin Neobothriocidaris Paul, 1967c in the following). The enormous diversity of early echinoderm 'designs' also poses a special challenge to recognizing homologies and to phylogenetic analysis. Extraxial skeletal elements are even more diverse. Plates are added almost anywhere, making it more difficult to recognize homologous elements. However, repeated extraxial designs do enable us to recognize distinctive (and possibly monophyletic) taxonomic groups.

Discussion is organized into four somewhat arbitrary sections, recognizing: (1) homologous ambulacra, (2) homologous oral plating, (3) homologous ambulacral plates, and (4) homologous cover plating, both oral and ambulacral. Most of the taxa discussed are referred to informally as 'cystoids,' which is shorter than 'noncrinoid pelmatozoans' and equates more or less to blastozoans but does not imply a formal taxonomic group.

\section{Homology versus analogy}

'Homology' may be defined as 'the same structure modified for different functions,' such as the forelimbs of ichthyosaurs, dinosaurs, and pterosaurs. Analogy involves different structures that perform the same function, such as the wings of birds and 


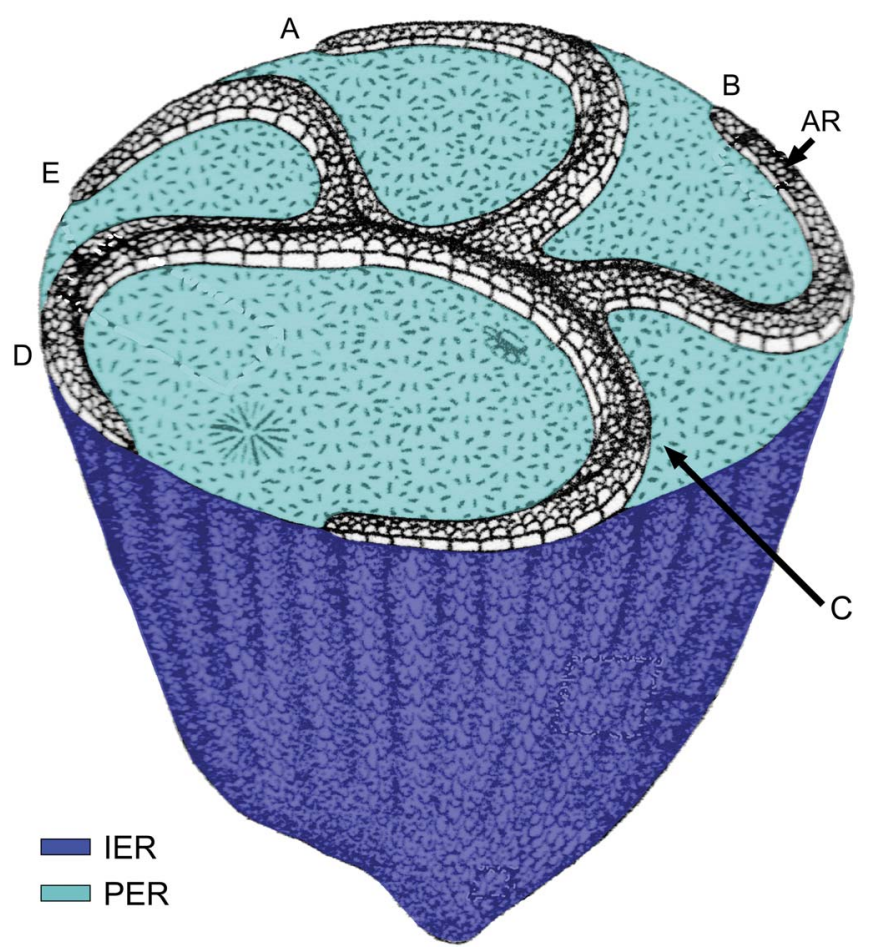

Figure 1. Illustration of extraxial-axial theory (EAT) using lower Cambrian Camptostroma Ruedemann, 1933 as an example. A-E = ambulacra in the Carpenter system (Carpenter, 1884, 1891); $\mathrm{AR}=$ axial region; IER = imperforate extraxial region; PER = perforate extraxial region. Redrawn from Paul and Smith (1984, fig. 19).

insects. Homology can be postulated initially using positional and developmental arguments. Such hypotheses of homology can be tested by comparison with the distribution of other postulated homologies (see Patterson, 1982, 1988 for a full discussion). In effect, homologous characters are synapomorphies, and the more postulated homologies involved in the analysis the stronger the test. A relevant example of positional evidence is the frequent development of five ambulacra in primitive echinoderms arranged in a '2-1-2' pattern (Bather, 1900, p. 11, fig. 9; Sprinkle, 1973, p. 43, fig. 16A) (Fig. 1). Three ambulacra leave the mouth, and the two opposite each other divide once to give a total of five. This pattern is particularly obvious in echinoderms with oral frames composed of just four plates (the peristomial border system type A2 of Kammer et al., 2013) and enables identification of individual ambulacra. The undivided ambulacrum is A under Carpenter's system (Carpenter, 1884, 1891), and clockwise in oral view the others are B, C, D, and E. The idea that these ambulacra are homologous in all echinoderms is strengthened by the fact that the hydropore always lies in the CD interradius. When only a single gonopore is present, this too is always in the CD interradius. However, the position of the anus is less reliable. In some early echinoderms, it also lies in the $\mathrm{CD}$ interradius, but it occurs in the BC interradius in glyptocystitoid rhombiferans and paracrinoids. See Sumrall (1997, p. 270, fig. 1) for another example of the positional argument applied to echinoderms.

Evolutionary tests include the distribution of characters in different major groups. For example, in glyptocystitoid rhombiferans, recumbent ambulacra (restricted here to ambulacra growing on top of thecal plates) have developed in the families Callocystitidae (virtually all genera) and Glyptocystitidae (only Glyptocystites Billings, 1954), but they have also developed in the diploporite family Holocystitidae (Paulicystis Frest and Strimple, 2011 in Frest et al., 2011) and in paracrinoids (Malocystites Billings, 1858). Rhombiferans, diploporites, and paracrinoids differ by so many other characters that recumbent ambulacra are likely to have evolved independently in each. Bockelie (1982) has demonstrated an evolutionary trend in caryocystitid rhombiferans from two through four ambulacra, whereas in both the diploporite families Sphaeronitidae and Holocystitidae and in the glyptocystitoid rhombiferans the trend was from five to four ambulacra. Thus, although in all cases ambulacrum $\mathrm{A}$ is missing, it seems this came about in two different ways (see the following). Again, caryocystitid rhombiferans and sphaeronitoid diploporites differ by many characters, so it is difficult to accept that ambulacrum A was lost once only.

On a purely practical note, if two different structures are thought to exist, it is better practice to record all relevant information as if they really differ. Then it should become apparent whether the differences are consistent and therefore significant, or whether they are merely end members of a continuum and only one variable structure exists. If alternatively it is initially assumed that only one structure exists, it will not become possible to distinguish between the two alternatives. In the present context, being cautious about assuming homology until there is evidence to support it is a better approach than assuming that homologies exist and not testing this assumption.

\section{The extraxial-axial theory}

Briefly, the extraxial-axial theory (EAT) is based on the fact that during echinoderm embryology, the water vascular system and all associated skeletal elements derive from the larval axocoel and first become evident at the rudiment stage. Furthermore, at least during the ontogeny of all known living echinoderms, axial skeletal elements are only added and any branching of the radial water vessels (including to lateral tube feet) only occurs terminally. Jackson (1912, p. 35-51, pl. 6, 7) first documented in anomalous sea urchins with $<5$ ambulacra that either the number of oculars coincided with the number of ambulacra, or occasionally, if the ocular corresponding to a missing ambulacrum was present, it lacked a terminal pore. Six ambulacra occurred in sea urchins with two terminal pores in one ocular plate. This led to the 'ocular plate rule' of echinoid coronal growth. Four columns of plates are added at the edges of the ocular plates in the apical system: two columns of ambulacral plates plus one column from each of the adjacent interambulacra. This means that echinoid interambulacra are not homologous with interambulacra of any other echinoderms (as pointed out by Mooi and David, 2008, p. 47). The only truly interambulacral structures in the echinoid corona are the interradial sutures. In starfish, the terminal radial plate secretes four columns of plates, two adradial ambulacral columns and a column of adambulacral plates on each side of the ambulacrals. The most obvious suggested homology here is that the four columns of plates in sea urchins are homologous with the ambulacral and adambulacrcal plates of starfish (notwithstanding their different positions with respect to the radial water vessels, 
i.e., internal in echinoids and external in starfish). Hence, position in this paper is referred to as radial or interradial, even though ambulacra are probably homologous in all echinoderms.

Extraxial skeletal elements and the associated body wall derive from the left and right somatocoels. Plates may be added anywhere within the extraxial skeleton making recognizing homologous plates extremely difficult. In early echinoderms, the extraxial skeleton is further divided into a perforate part, which usually includes the 'cystoid' theca and commonly has various pore structures in it, and an imperforate part, which commonly includes the stem or column when present and lacks pore structures (Fig. 1). Much early echinoderm evolution can readily be understood in terms of changes in the relative importance of the axial, perforate, and imperforate extraxial skeleton (e.g., Lefebvre et al., 2015).

The EAT is based on embryological information, which can only be derived from living echinoderms. Paleozoic echinoderms may have grown in a different manner. Post-Paleozoic echinoids form a monophyletic group whose roots lie in the late Paleozoic Miocidaridae, the corona of which is characterized by 20 columns of plates: five pairs of columns of ambulacral plates bearing pores for tube feet, and five pairs of 'interambulacral' columns. This pattern has since been inherited by all postPaleozoic sea urchins, which also display the ocular plate rule. Several genera of Paleozoic echinoids have different coronal plate arrangements, including multiple columns of ambulacral and/or interambulacral plates (Kier, 1965). Neobothriocidaris (Fig. 2) is relevant here because its radial water vessels and side branches to tube feet lie within the coronal plates, so its water vascular system can be reconstructed accurately. The corona consists of single columns of imperforate plates, beside which are multiple rows of ambulacral plates bearing tube feet and arranged in a chevron pattern (Fig. 2.1). Pore pairs for tube feet are shared by two adjacent ambulacral plates, and each was fed by a lateral branch of the radial water vessel (Fig. 2.2). Figure 2.1 shows at least two new ambulacral plates that do not reach the full width of the row of plates to which they belong (arrows). Hence, ambulacral plates were added adjacent to the plates in the single columns of imperforate plates in Neobothriocidaris.

As new ambulacral plates were added, new lateral branches of the radial water vessels were produced (Fig. 2.2). Thus, without doubt in Neobothriocidaris, the radial water vessels were able to branch anywhere along their length. The single columns of imperforate plates in Neobothriocidaris are radial because they contained the radial water vessels, and Paul (1967c) argued that each column was homologous with the single ocular plate of other sea urchins. Thus, addition of ambulacral plates adjacent to a column of 'ocular' plates can be said to comply with the ocular plate rule.

This interpretation also made better sense of the apical disc of Bothriocidaris (Fig. 2.3), which apparently differed from all other sea urchins in having only five radial plates (oculars), one of which was modified as the madreporite (hydropore), and therefore lacked not only genital plates but any evidence of gonopores too. However, if in Bothriocidaris the single columns of plates are homologous with ocular plates and radial in position, the five plates in the apical disc become interradial (genitals), one of which is modified as the madreporite and hence defines the CD interradius (as in all other sea urchins). Nevertheless, Bothriocidaris remains puzzling as the supposed primary ambulacral plates apparently obey Lovén's law (Lovén, 1874) under the conventional interpretation (see discussion in Paul, 1967c, p. 538).

The principal point here is that the EAT is based on information from living echinoderms and may not apply universally to fossil echinoderms. Post-Paleozoic crinoids (see Simms, 1999) and asteroids (e.g., Gale, 2011) may also be derived from one or a few taxa that survived the end Paleozoic mass extinction and form monophyletic groups. Certainly one assumption of the EAT, that branching of radial water vessels was always terminal, does not apply to Neobothriocidaris and possibly to other early Paleozoic echinoids with multiple columns of
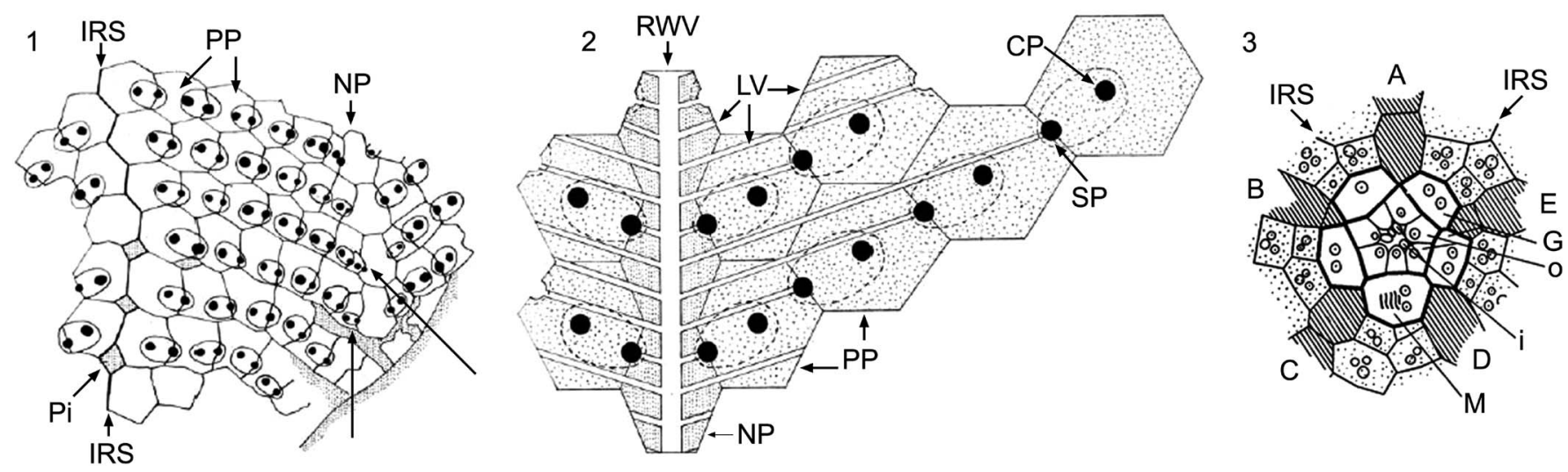

Figure 2. Morphological features of $(\mathbf{1}, \mathbf{2})$ Neobothriocidaris and (3) Bothriocidaris. (1) Camera lucida drawing of part of the test to show the arrangement of poriferous plates (PP) in rows and nonporiferous plates (NP) in a column. IRS = interradial suture; Pi = pit. The most recently added poriferous plates are arrowed. Redrawn from Paul (1967c, fig. 2). (2) Reconstruction of part of the water vascular system in Neobothriocidaris. CP $=$ central pore; LV = lateral vessel; NP = nonporiferous plates; PP = poriferous plates; RWV = radial water vessel; $\mathrm{SP}=$ sutural pore. During growth, new lateral vessels feeding the pore pairs must have been added along the entire length of the radial water vessel. Redrawn from Paul (1967c, fig. 6). (3) The apical disc of Bothriocidaris, as reinterpreted by Paul (1967c). Each radius consists of a central per-radial column of plates (diagonal shading) flanked by two columns of ambulacral plates (stippled). The large plates in the apical disc become genitals $(\mathrm{G})$, one of which is modified as the madreporite (M) and defines the $\mathrm{CD}$ interradius. A-E = radii under Carpenter's system; i and o = inner and outer periproctal cover plates; IRS = interradial sutures defining the limits of ambulacrum A. Redrawn after Männil (1962, fig. 1) and Solovjev (2009, fig. 1). 
ambulacral plates. Nevertheless, the EAT and its inherent assumptions are the best theoretical concept on which to investigate homologies of the axial skeleton in early echinoderms.

\section{Homology of ambulacra}

Several systems of denoting ambulacra in echinoderms have been developed, but recently Carpenter's system (Carpenter, 1884, 1891) (Fig. 3) has found favor. In oral view, the ambulacrum opposite the hydropore is denoted as ambulacrum $\mathrm{A}$; the others are labeled B-E clockwise. Interradii are denoted by the letters of the ambulacra that bound them. So the interradius containing the hydropore is the $\mathrm{CD}$ interradius. The hydropore is favored as the prime datum because it arises earliest in echinoderm ontogeny and survives in the same position in adults. However, when there is a single gonopore, this is also located in the $\mathrm{CD}$ interradius. Functional gonopores arise much later in ontogeny than the hydropore, and echinoids possess five gonopores so they cannot be used for orientation. In many early echinoderms, the periproct also lies in the CD interradius, but it is much more mobile. Not only does it sometimes appear on the oral surface (in the rhombiferan family Caryocrinitidae), or laterally in the theca (in the related rhombiferan family Hemicosmitidae), but it is also found in the $\mathrm{BC}$ interradius in the rhombiferan superfamily Glyptocystitoida and in paracrinoids. Finally, Sprinkle (1973, p. 43, fig. 16) pointed out that many early echinoderms had ambulacra arranged in a 2-1-2 pattern (Fig. 3). Consistently, the single ambulacrum is A. Thus, even when neither hydropore nor gonopore can be detected, it may still be possible to identify homologous ambulacra using this 2-1-2 pattern. A symmetry plane that bisects the A ambulacrum and the CD interradius is useful in discussing positions of hydropore and gonopore in different echinoderm groups.

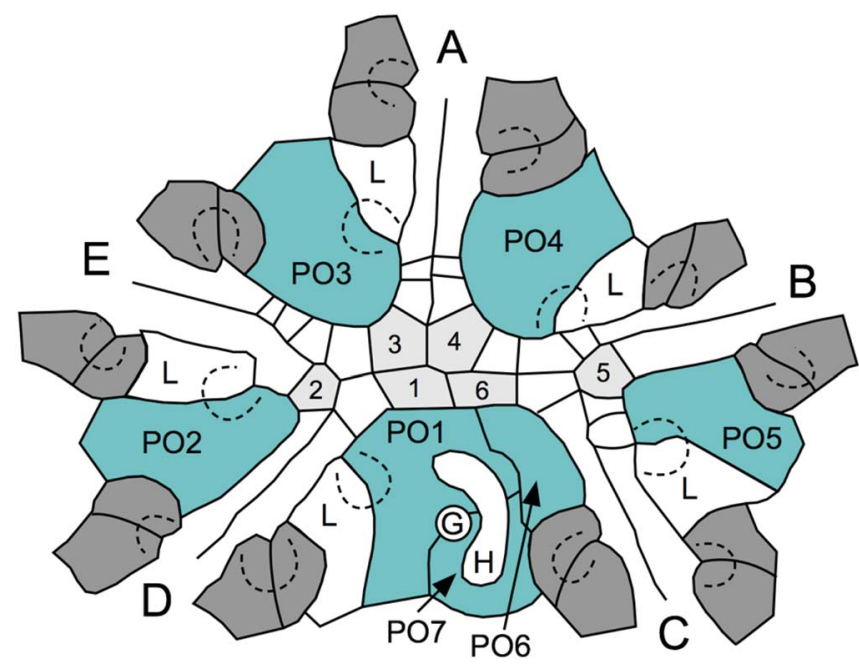

Peri-oral plates $\square$ Ambulacral floor plates $\square$ Primary oral cover plates

Figure 3. Camera lucida drawing of the oral surface of the glyptocystitoid rhombiferan Lepadocystis moorei (Meek, 1871) (University of Cincinnati 57349). $\mathrm{A}-\mathrm{E}=$ Carpenter ambulacra; $\mathrm{G}=$ gonopore; $\mathrm{H}=$ hydropore; $\mathrm{L}=$ "first left ambulacral floor plates" of Sumrall and Waters (2012); PO1PO7 $=$ peri-oral plates; $1-6=$ primary ambulacral cover plates. Modified from Sumrall and Waters (2012, p. 958, fig. 1).
For example, the hydropore is typically to the right of this plane in edrioasteroids, but more commonly on it or to the left in 'cystoids.'

It is now believed that the 2-1-2 pattern of ambulacra reflects the evolutionary history of the echinoderms. Derstler (1981) and Paul and Smith (1984, p. 449, fig. 4) independently interpreted helicoplacoids as having three ambulacra, two ascending from the lateral mouth and one descending. Paul and Smith suggested that the single descending ambulacrum might be homologous with the A ambulacrum of pentameral echinoderms and the two ascending ambulacra were homologous with the $\mathrm{B}+\mathrm{C}$ and $\mathrm{D}+\mathrm{E}$ ambulacra, even though no evidence of the gonopore, hydropore, or periproct was known in helicoplacoids (and still is not). Smith and Rahman CT scanned a helicoplacoid, which showed no evidence of a lateral periproct (personal communication, A.B. Smith, 2015). They concluded that the periproct of helicoplacoids was apical (Smith and Zamora, 2013, p. 4), i.e., associated with the two ascending ambulacra, which supports the previously suggested homology of helicoplacoid ambulacra. Although this was an inference not supported by direct observation, the only alternative is that helicoplacoids had a blind gut, which seems even less likely.

Building on Bell's (1976a, b) earlier work on edrioasteroid ambulacral development, Sumrall and Wray (2007) reviewed both the number and symmetry of the ambulacra in Paleozoic echinoderms. They argued that during ontogeny in most Paleozoic echinoderms, the ambulacra developed in three distinct phases; first the two shared lateral ambulacra (B + C and $\mathrm{D}+\mathrm{E})$ appeared, then ambulacrum A was added, and finally both lateral ambulacra divided once to give five (Fig. 4).

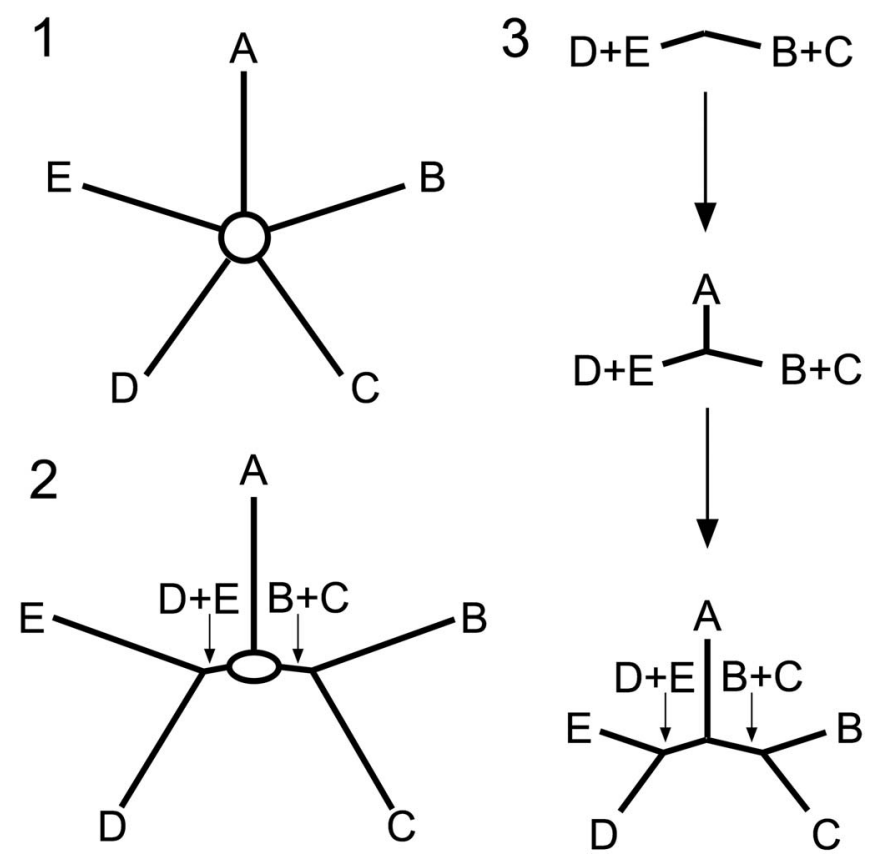

Figure 4. True pentamery (1) where all five ambulacra leave the mouth individually versus (2) the 2-1-2 pattern in which three primary ambulacral grooves $(\mathrm{A}, \mathrm{B}+\mathrm{C}$, and $\mathrm{D}+\mathrm{E})$ leave the mouth before the lateral ambulacra bifurcate to give five ambulacra. (3) The supposed order of ambulacral development under the paedomorphic ambulacral reduction (PAR) model of Sumrall and Wray, 2007. First, the lateral primary ambulacra $(B+C$ and $D+E)$ develop, then ambulacrum $\mathrm{A}$ is added, and finally the lateral ambulacra divide. Redrawn from Sumrall and Wray (2007, p. 150, fig. 1). 
They explained 'aberrant' symmetry with fewer than five ambulacra by their paedomorphic ambulacral reduction (PAR) model, in which combinations of these growth stages were lost during ontogeny. They also distinguished 'true fivefold' symmetry, in which all five ambulacra enter the mouth separately, from the 2-1-2 ambulacral symmetry, which is fundamentally triradiate. These subdivisions form a useful basis for discussing homologous ambulacra in 'cystoids' and other echinoderms.

Sumrall and Wray (2007, p. 155, fig. 6) summarized the results of their survey by plotting on a phylogenetic tree the occurrence of the seven types of ambulacral symmetry they recognized. They showed that each symmetry type appeared more than once on the tree under any character optimization. Their fundamental conclusion was that distantly related groups of early echinoderms repeatedly modified the basic pentaradial symmetry characteristic of the phylum. Even so, I think the situation is even more complicated. Patterns of ambulacral reduction were achieved in different ways. For example, although all early echinoderms with four ambulacra lack ambulacrum A, this was derived through two evolutionary pathways. It is currently fashionable to ignore stratigraphy in deriving evolutionary relationships, yet stratigraphy does put minimum ages on the appearance of characters as well as taxa. The diploporite families Sphaeronitidae and Holocystitidae both include genera with five and four ambulacra. In sphaeronitids, five ambulacra appear in Glyptosphaerites Müller, 1854 and Palaeosphaeronites Prokop, 1964 (Tremadocian, Lower Ordovician), but genera with four ambulacra, such as Tetreucystis Bockelie, 1984 and Diplosphaeronis Paul, 1973 are unknown before the Katian (Upper Ordovician). Similarly, in the Holocystitidae, Brightonicystis (five ambulacra, Hirnantian, Upper Ordovician) appears well before genera with four (Trematocystis Jaekel, 1899; Pustulocystis Paul, 1971, Wenlock, lower Silurian). Thus, in these two families, which are united by the possession of dipores, a palate of six plates, and homologous circum-oral plates (see next section), evolution would seem to have proceeded from five to four ambulacra (Fig. 5). By contrast, Bockelie (1982, p. 493, fig. 2) documented parallel evolutionary trends in the caryocystitid rhombiferans Echinosphaerites Wahlenberg, 1821 and Heliocrinites Eichwald, 1840 from two through four ambulacra (Fig. 6). In a related genus, Caryocystites von Buch, 1846, the trend went only from two to three. These caryocystitid rhombiferans share humatirhombs and only five peri-oral plates (see next section). Thus, Echinosphaerites and Heliocrinites achieved species with four ambulacra by an opposite route to sphaeronitids and holocystitids. Incidentally, no holocystitid has three ambulacra. I presume Sumrall and Wray (2007, fig. 6) were referring to Triamara Tillman, 1967. Although S. A. Miller and coworkers described six nominal species of Triamara under the name Holocystites in the late nineteenth century (e.g., Miller 1879, 1891), Triamara belongs in the diploporite family Aristocystitidae.

Sumrall and Wray (2007, p. 156, fig. 7) also indicated how they thought the primitive 2-1-2 pattern of five ambulacra might have become pseudo-fivefold by shortening the length of the shared portions of ambulacra $\mathrm{B}+\mathrm{C}$ and $\mathrm{D}+\mathrm{E}$. In at least some 'cystoids,' this appears to have occurred by the enlargement of the oral opening. For example, in aristocystitids whether with 2,3 , or 4 ambulacra, the mouth is a relatively narrow opening that lies entirely within the two lateral ambulacra (Fig. 7). In the eocrinoid Rhopalocystis Ubaghs, 1963 (Fig. 8) and the diploporite families Sphaeronitidae and Holocystitidae (Fig. 5), the oral opening is much larger than the ambulacral grooves, which all arise separately from the edge of the mouth, whether four or five ambulacra are developed. Kammer et al. (2013) make the same point in recognizing the difference between their peristomial border systems type A 2 and A 3 .

Tables 1 and 2 (supplementary material) summarize my interpretation of which ambulacral patterns are present. The tables attempt to include at least one example of every ambulacral pattern known within the major taxa listed. Variation in ambulacral patterns is considerable and there remain numerous early echinoderms whose ambulacral patterns are uncertain.

I think the PAR model of Sumrall and Wray (2007, figs. 6 and 7) was a useful initial concept, but it can be extended. For example, their figure 6 implies that all triradiate echinoderms have an ambulacral pattern of $\mathrm{A}, \mathrm{B}+\mathrm{C}, \mathrm{D}+\mathrm{E}$. This is true of the hemicosmitoid rhombiferans Hemicosmites von Buch, 1840, Caryocrinites Say, 1825, Juglandocrinus von Koenen, 1886, Paracaryocrinites Chen and Yao, 1993, and Stribalocystites Miller, 1891 (Lanc et al., 2015) (Fig. 9), but not of the caryocystitoid rhombiferans Caryocystites, Echinosphaerites, and Heliocrinites with three ambulacra because ambulacrum A is never present in these genera (Bockelie, 1982) (Fig. 6). Furthermore, the echinoencrinitid rhombiferan Tyrridiocystis Broadhead and Strimple, 1978 has B, C, and D + E (Broadhead and Strimple, 1978) (Fig. 10), whereas the aristocystitid diploporite Triamara has B $+\mathrm{C}, \mathrm{D}$ and $\mathrm{E}$ (Paul, 1971). Whether Trimerocystis Schuchert, 1904 is a teratological specimen of the callocystitid rhombiferan Pseudocrinites Pearce, 1843 (as suggested by Kesling, 1961, p. 258) or a valid genus, it has three ambulacra, B, C, and E. Kesling (1961, fig. 2b) illustrated a specimen of the callocystitid rhombiferan Jaekelocystis hartleyi Schuchert, 1903 with ambulacra E, A, and B and (Fig. 3b) another in which ambulacrum D was very short. Finally, I recall a teratological example of the callocystitid rhombiferan Lepadocystis moorei (Meek, 1871) in the Field Museum, Chicago, which had only ambulacra A, D, and E. Thus, just with threerayed genera and anomalous individuals, a variety of patterns exists.

To grow all the variety of ambulacral structures seen in primitive echinoderms requires only three instructions: 'grow,' 'branch,' and 'stop growing.' Thus, in one sense, all cases of echinoderms with fewer than five ambulacra must arise by paedomorphosis, since the 'stop' instruction must happen very early in development. Nevertheless, the simple pattern of ambulacral addition indicated by Sumrall and Wray (2007, fig. 1) (Fig. 4) did not exist as a developmental pattern in early echinoderms. If it did, echinoderms with four and one ambulacrum would not exist. I suspect that ambulacral growth was controlled by developmental genes, which not only could be turned off to reduce the number of ambulacra, but acted entirely independently in each ambulacrum. So, for example, to get the three-rayed pattern of Tyrridiocystis (Fig. 10) and Triamara required turning ambulacrum $\mathrm{A}$ off in both, but then branching only the $\mathrm{B}+\mathrm{C}$ ambulacrum in the former and only the $\mathrm{D}+\mathrm{E}$ ambulacrum in the latter. Whether all two-rayed forms have $\mathrm{B}+\mathrm{C}$ and $\mathrm{D}+\mathrm{E}$, or some other pattern, such as the $\mathrm{C}$ and $\mathrm{E}$ 


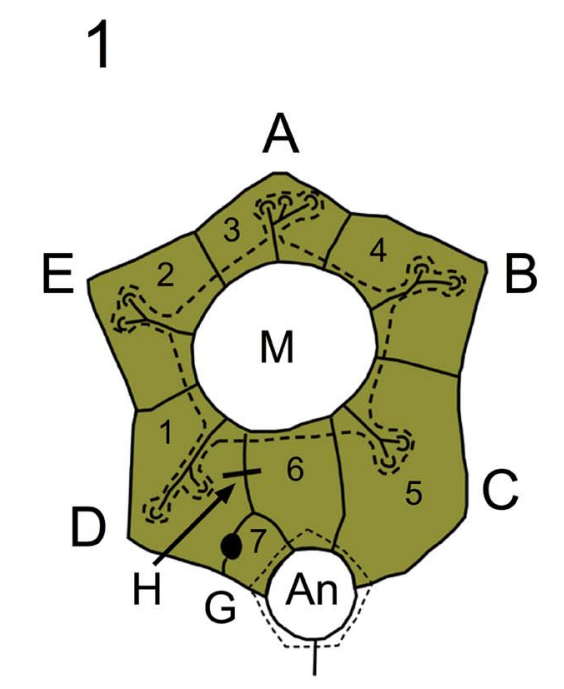

2
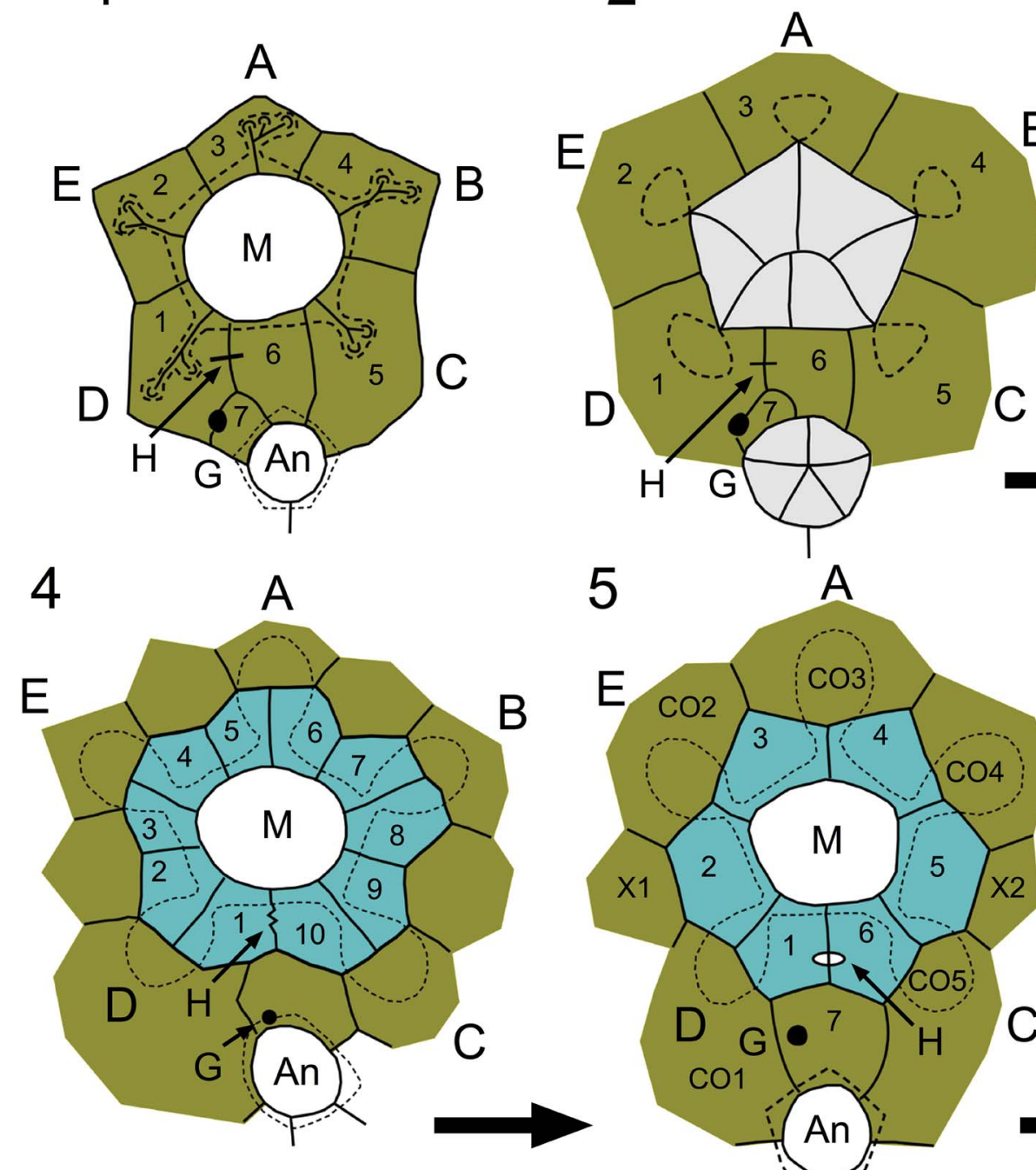

4

5

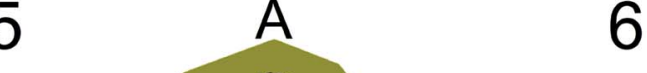

3

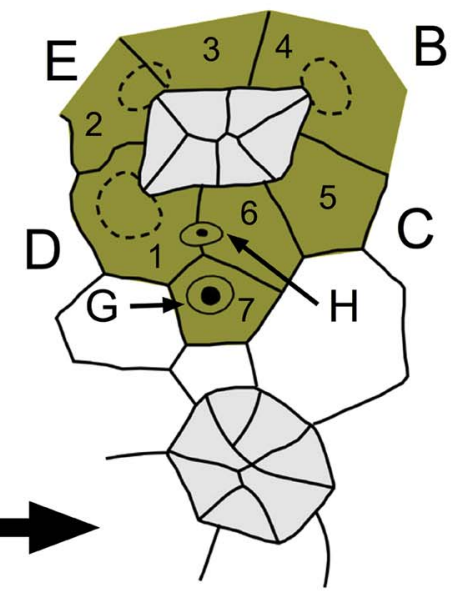

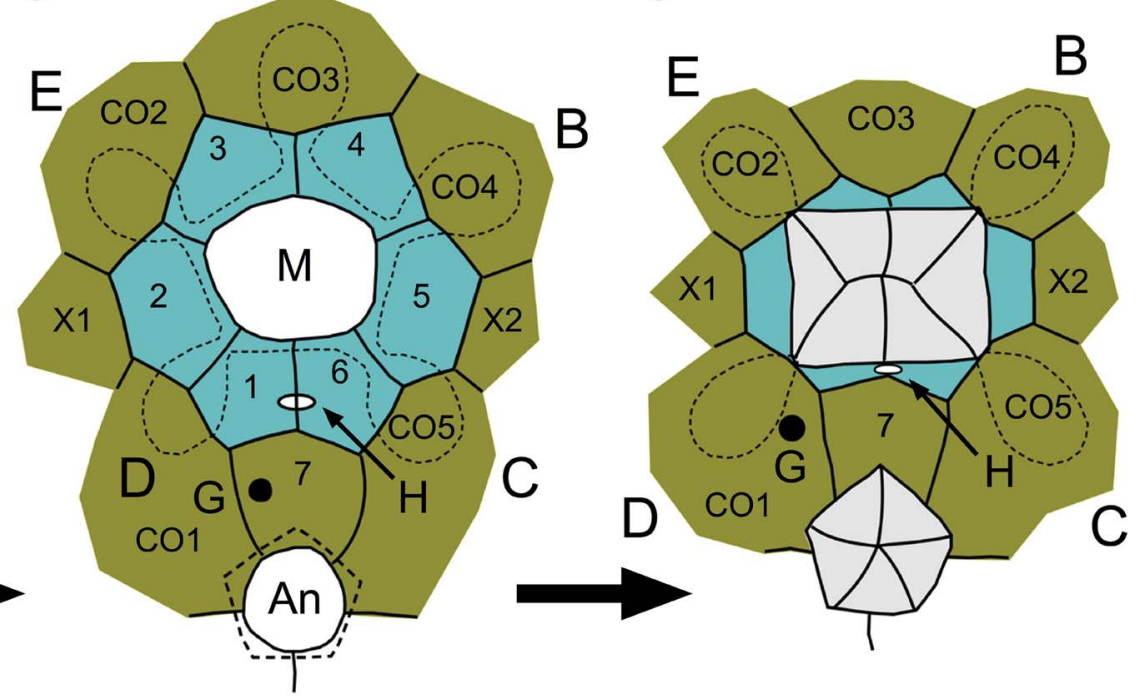

B

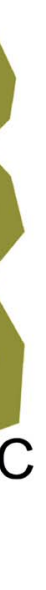

Oral and anal cover plates

Figure 5. Reduction of ambulacra from five to four and plating around the mouth (M) in the diploporite families (1-3) Sphaeronitidae and four to six Holocystitidae. (1) Eucystis angelini Regnéll, 1945. (2) Haplosphaeronis oblonga (Angelin, 1878). (3) Diplosphaeronis laevis Paul, 1973. (4) Brightonicystis gregaria Paul, 1971. (5) Holocystites cylindricus (Hall, 1861). (6) Trematocystis globosus (Miller, 1878). In the Sphaeronitidae, six circum-oral plates (1-6) surround the mouth; five are radial and the sixth lies in the CD interray. A small seventh plate (7) associated with the gonopore $(\mathrm{G})$ lies below and to the left of the other six plates. Food grooves radiate from the corners of the peristome and frequently end in several small facets (1), but occasionally larger facets are developed (3). In both families, the hydropore $(\mathrm{H})$ is associated with the suture between the two plates in the CD interradius. The mouth (M) is covered by six palatal plates and the anus (An) by a simple anal pyramid. (4) The holocystitid Brightonicystis has five pairs of plates surrounding the mouth (1-10) and an eleventh with the gonopore. (5) Other holocystitids have six interradial peri-oral plates (1-6) and a seventh often associated with the gonopore. (3, 6) In both families, when only four ambulacra are present, ambulacrum A is not developed, but plate CO3 is. Large arrows indicate inferred direction of evolution. Redrawn from Paul (1973, p. 13, fig. 8). A-E = ambulacra; CO1-CO5 = circum-oral plates; X1, X2 = extra plates in the circum-oral circlet.

pattern of the callocystitid rhombiferan Pseudocrinites (Jaekel, 1899; Kesling, 1961) depends on the oral plating, which now needs to be considered more fully. Pseudocrinites is a particularly interesting case in the context of the PAR model. It has only two ambulacra, in both of which the first two brachioles branch to the left. Thus, developmental arguments suggest the two ambulacra are homologous with the B and D ambulacra of pentameral callocystitids, which also have the first two facets to the left. However, one of the ambulacra passes between the periproct and the gonopore and hydropore. Positional arguments show that this ambulacrum in callocystitids with five (or four) ambulacra is always ambulacrum $\mathrm{C}$ and the ambulacrum opposite is $\mathrm{E}$. Thus, if one accepts the developmental argument, these two ambulacra have rotated on the theca. Alternatively, if one accepts the positional argument, the two ambulacra have developed extra brachioles. Knowledge of the oral plating could settle the argument since $\mathrm{O} 1$ is always associated with ambulacrum D, O2 with $\mathrm{E}$, and so on, but unfortunately the only illustration of the orals in Pseudocrinites (Paul, 1967a, p. 325, fig. 16) is completely wrong. It resulted from a combination of 

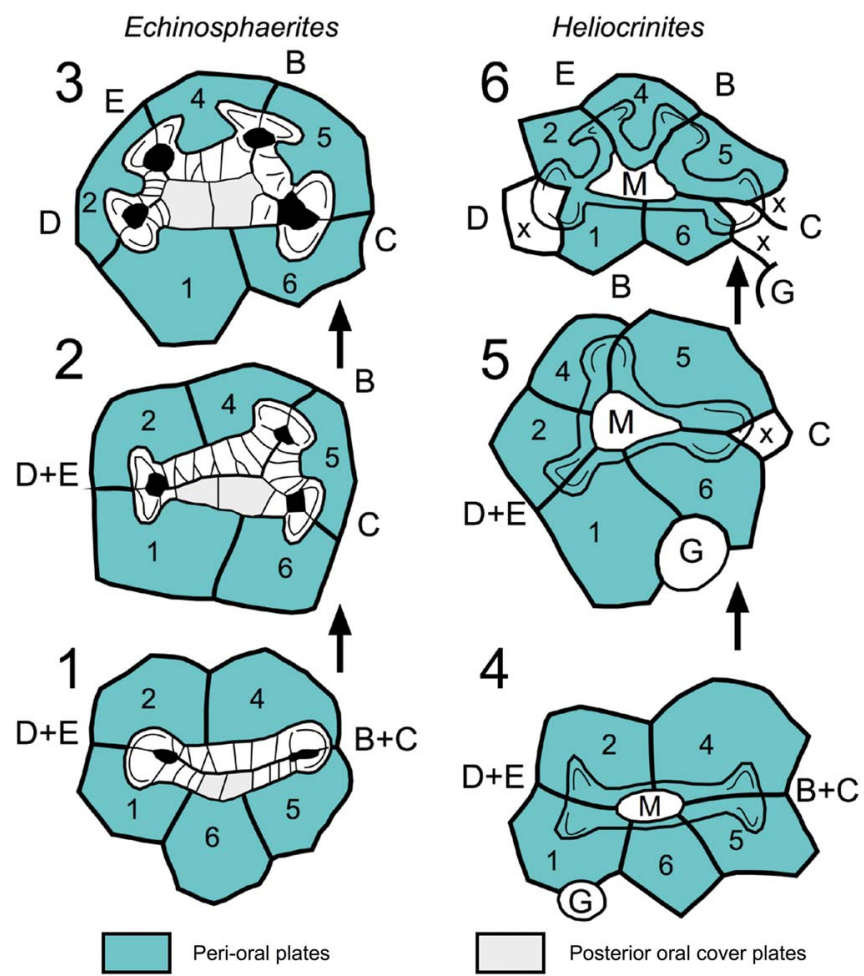

Figure 6. Increase in ambulacra from two to four and plating around the mouth (M) in rhombiferan families (1-3) Echinosphaeritidae and (4-6) Caryocystitidae. In caryocystitoid rhombiferans, five interradial plates (here interpreted as peri-orals 1-2 and 4-6) form an oral prominence. Increase in the number of ambulacra does not increase number of peri-orals, but extra plates (x) may contribute to ambulacral facets of Heliocrinites. (1-3) Ambulacral grooves are covered by cover plates, two of which in the $\mathrm{CD}$ interray (shaded) may become very large. A hydropore is unknown. $\mathrm{B}-\mathrm{E}=$ ambulacra; $\mathrm{G}=$ gonopore. Arrows indicate direction of evolution. Redrawn from Bockelie (1982, p. 493, fig. 2).

fortuitous cracks and wishful thinking, but is obviously wrong. The orals surround the mouth; they cannot all be visible on one side of it.

\section{Homology of oral plates}

Without knowledge of the oral plating, the taxonomic affinities of most early echinoderms remain uncertain. Sumrall (e.g., 2010, p. 269 and elsewhere) has rightly pointed out that giving a series of plates the same name does not mean the plates are homologous in different echinoderm groups, but merely implies it. This is just as true of oral plates as of basals, laterals, or deltoids. Equally, however, assigning different names may obscure homology, as with echinoid interambulacral and asteroid adambulacral plates. The current scheme of plate notation in lenticular paracrinoids (Parsley and Mintz, 1975) is particularly unhelpful in identifying the oral plates. Thus, the homology of oral plates in different early echinoderms needs to be tested, and those with unusual arrangements can be used as a test. It is immediately apparent that the number of oral plates does not correlate with the number of ambulacra in several major groups (e.g., the caryocystitoid rhombiferans, Fig. 6). Thus, the assumption that the orals of 'cystoids' are homologous with primary ambulacral plates (as in other echinoderm classes) needs consideration.
Kammer et al. (2013) have recently considered this aspect in detail. They made a fundamental distinction between oral frames composed exclusively of interradially positioned plates, which they called 'orals' and which constituted their type A peristomial border system (PBS), and those composed of radially positioned plates, which they called 'oral frame plates' (their PBS type B). They recognized four different subtypes of type A oral frames and two of type B. Type A1 involved paired ambulacral flooring plates as well as the usual seven 'orals.' It was recognized only in the middle Cambrian edrioasteroids Kailidiscus Zhao et al., 2010 and Walcottidiscus Bassler, 1935. Types A2 and A3 were distinguished by having four or six 'orals' forming the mouth frame, respectively. In the former, the 2-1-2 pattern of ambulacra is obvious, but it is absent in the latter, where all five food grooves enter the mouth separately. Types A2 and A3 were characterized by the glyptocystitid rhombiferan Lepadocystis Carpenter, 1891 (Fig. 3) and the eocrinoid Rhopalocystis (Fig. 8), respectively. Type A4 also had six plates forming the peristome frame, but differed in having the mouth covered by just five primary peristomial cover plates. It was characterized by three genera of crinoids.

Type B1 was characterized by having five oral frame plates closest to the mouth and in contact with the 'orals' more distally, whereas type B2 had an oral frame composed of just the five oral frame plates. Both were exemplified by edroasteroid genera.

My own ideas are remarkably similar, despite being based on different genera of early echinoderms. I certainly agree that radial versus interradial positioning is a fundamental distinction in recognizing types of oral frame plates in early echinoderms. Paul (1971, p. 71) introduced the term 'peri-orals' for interradially positioned 'orals' in the diploporite family Holocystitidae, the equivalent of Kammer et al.'s (2013) 'orals.' Paul (1973, pp. 12, 13, fig. 8) introduced the term 'circum-orals' for the radially positioned 'orals' in the diploporite family Sphaeronitidae, the equivalent of Kammer et al.'s (2013) 'oral frame plates.' Although not explicitly stated, this was to avoid any implied homology between the two types of oral frames and because the oral cover plates of sphaeronitids had also previously been referred to as 'orals' (e.g., Prokop, 1964, p. 13). Paul (1971, p. 6, fig. 1) also introduced the term 'palate' for the cover of the mouth in both holocystitids and sphaeronitids, which is composed of six primary oral cover plates or 'palatals.' All three terms, peri-orals, circum-orals, and palatals, are still useful and will be used here.

In the 1960s and 1970s, it was fashionable to emphasize differences between major groups of echinoderms. However, with the rise of cladistics, it has become more common and more profitable to seek similarities between such groups. So, in the early 1970s, I was concerned not to imply unwarranted homologies by using the same term 'orals' for plates I did not think were homologous. Now, I would go further and suggest that radially positioned oral plates, the circum-orals, may well be homologous in whatever echinoderm they occur. Similarly, interradially positioned orals, my peri-orals, may also be homologous wherever they occur, although there are some reasons to doubt this. Thus, I now think the diploporite family Sphaeronitidae is characterized by the loss of the peri-oral circlet and the retention of circum-orals to form the mouth frame (Fig. 5.1-5.3). The diploporite family Holocystitidae has both 

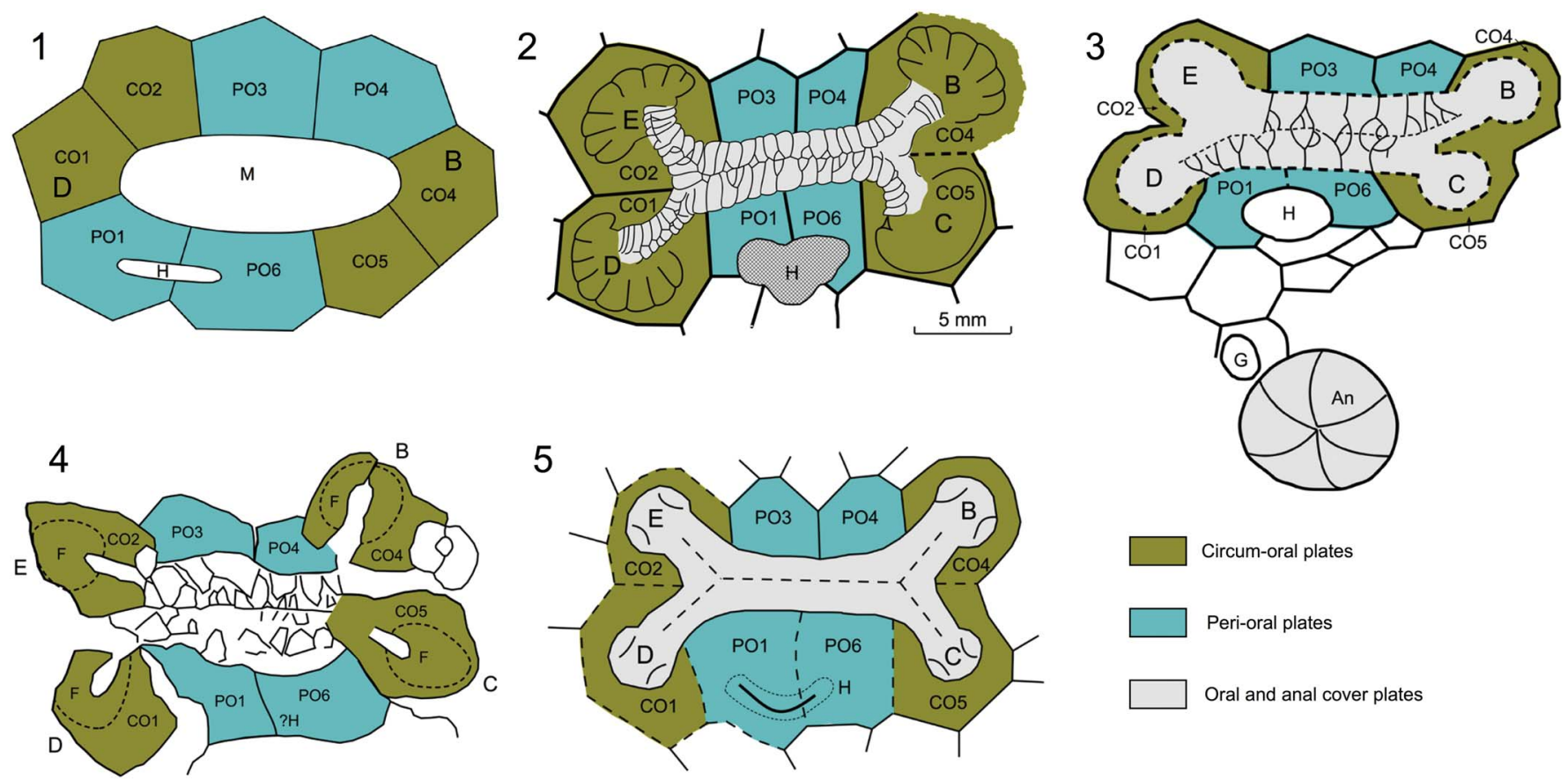

Figure 7. Ambulacra and oral plating in aristocystitid diploporites. (1) Aristocystites Barrande, 1887. (2) Calix sedgwicki Rouault, 1851. (3) Glaphocystis Chauvel, 1966. (4) Lepidocalix Termier and Termier, 1950. (5) Sinocystis Reed, 1917. In aristocystitids the mouth (M) lies within a broad food groove, which extends left and right. (2) The food grooves are covered with a double biseries of cover plates. (1) In Aristocystites, a single large facet lies at each end of the food groove. (2) In Calix, both food grooves divide to give four large facets from which up to four brachioles arise. In (3) Glaphocystis, (4) Lepidocalix, and (5) Sinocystis, the four facets apparently gave rise to a single appendage. $\mathrm{An}=$ anus; $\mathrm{B}-\mathrm{E}=$ ambulacra; $\mathrm{CO} 1-\mathrm{CO} 5=$ circum-oral plates; $\mathrm{F}=$ ambulacral facets; $\mathrm{G}=$ gonopore; $\mathrm{H}=$ hydropore; PO1-PO6 = peri-oral plates. (1) Redrawn from Parsley (1990, p. 286, fig. 2). (2) Redrawn from Chauvel (1977, p. 315, fig. a). (3) Redrawn from Chauvel (1966, pl. 4, fig. 1E). (4) Redrawn from Makhlouf et al. (in press, fig. 6, A2). (5) Redrawn from Bather (1918, p. 535, fig. 9). Dashed plate sutures inferred.

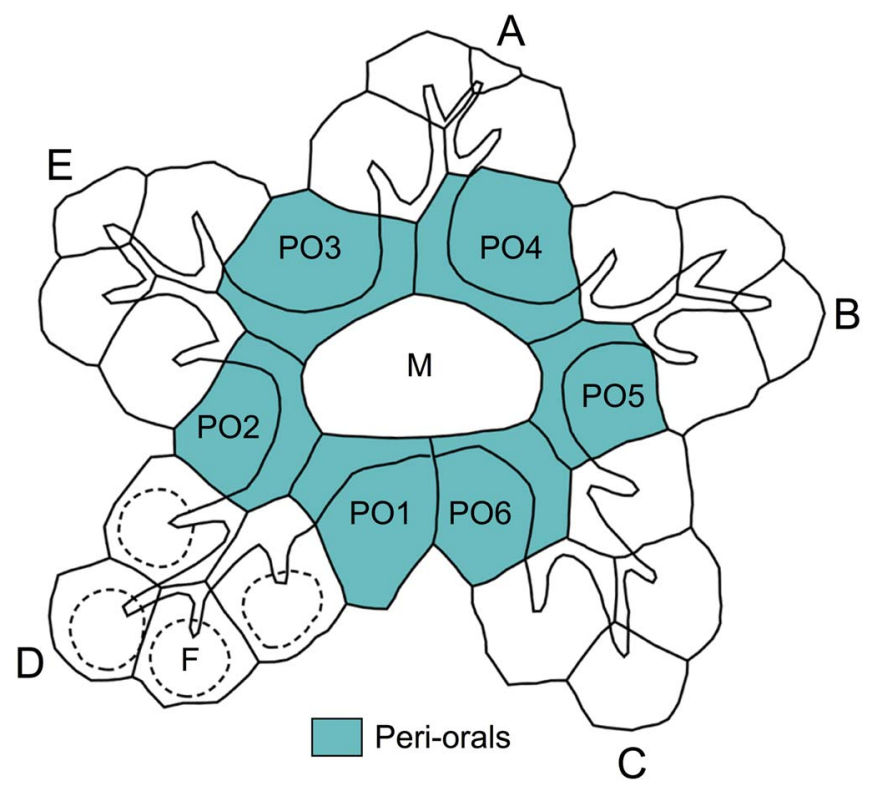

Figure 8. Ambulacra and oral plating in the 'eocrinoid' Rhopalocystis. $\mathrm{A}-\mathrm{E}=$ ambulacra; $\mathrm{F}=$ ambulacral facet (only shown in amb D). $\mathrm{M}=$ mouth; PO1-PO6 = peri-oral plates. Redrawn after Ubaghs (1963, fig. 7, p. 33). Note the peri-orals lack brachiole facets.

peri-orals, forming the mouth frame, and circum-orals (previously called facetal plates, Paul, 1971) (Fig. 5.5, 5.6). If one accepts this idea, then any suggested homology between circum-orals and peri-orals can be rejected on the conjunction test of Patterson $(1982,1988)$, which states that two supposedly homologous structures cannot be present in the same organism. I would also suggest a further test of whether the new interpretation improves our understanding of early echinoderm relationships. Here I would argue that it does because I can suggest new interpretations of the oral plating of the diploporite families Aristocystitidae (Fig. 7) and Parasphaeronitidae (Fig. 11), both of which have at least eight plates associated with their oral areas.

As far as Kammer et al.'s (2013) types of peristomial border systems are concerned, among 'cystoids,' the unique holocystitid diploporite Brightonicystis Paul, 1971 (Fig. 5.4) and those hemicosmitoid rhombiferans in which the oral surface is not hidden by a tegmen (Fig. 9.1, 9.2, 9.4) have oral frames in which pairs of ambulacral plates are involved. They constitute a type of oral plating at least analogous to Kammer et al.'s type A1. I would emphasize the distinction between incorporating pairs of ambulacral plates and only incorporating the first ambulacral plate into the oral frame rather more than Kammer et al. (2013) did.

I agree with Kammer et al.'s (2013) types A2 and A3, although I would point out that Paul and Donovan (2011, p. 448, fig. 14) illustrated two examples of the same rhombiferan species, Glansicystis glans Paul (in Paul and Donovan, 2011), which fall into both groups (see Fig. 12.1, 12.2). I suspect the difference arises because the oral area retains more or less sediment, but it could also be due to changes during growth.

Kammer et al.'s (2013) type A4 differs primarily from A3 by their interpretation of the oral cover plates; that is, a palate is 

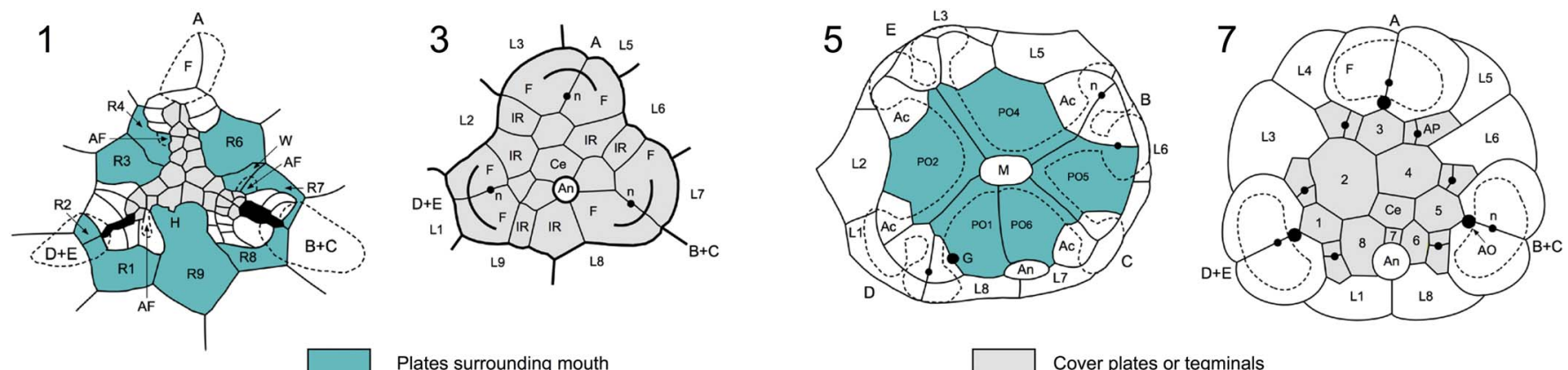

Plates surrounding mouth
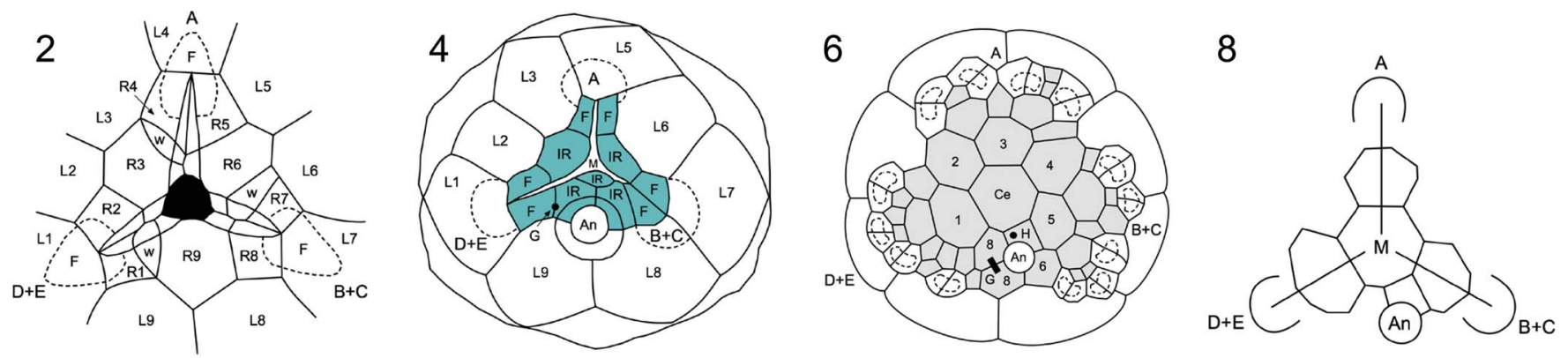

Figure 9. Oral areas in hemicosmitoid rhombiferans. (1) Hemicosmites pyriformis von Buch, 1840 (holotype). (2) H. pyriformis to show oral plating. (3) Juglandocrinus sdzuyi (Chauvel and le Menn, 1979). (4) Paracaryocrinites sp. (5) Thomacystis tuberculata Paul, 1969. (6) Caryocrinites ornatus Say, 1825. (7) Stribalocystites tribrachiatus (Frest, 1975). (8) Diagrammatic representation of ambulacra and mouth in Caryocrinitidae. Apart from (5) Thomacystis, all hemicosmitoids have three ambulacra (A, B + C, D + E). (6) In Caryocrinites s.s., all three ambulacra branch, so lateral groups of facets do not represent separate ambulacra $\mathrm{B}-\mathrm{E}$. $\mathrm{Ac}=$ accessory plates; $\mathrm{AF}=$ accessory facet; $\mathrm{An}=$ anus; $\mathrm{AO}=$ ambulacral orifice; $\mathrm{AP}=$ accessory pore; $\mathrm{Ce}=$ central tegminal plate; $\mathrm{F}=$ facetal plates; $\mathrm{G}=$ gonopore; $\mathrm{H}=$ hydropore; $\mathrm{IR}=$ interradial plates; $\mathrm{L} 1-\mathrm{L} 9=$ lateral plates; $\mathrm{M}=$ mouth; PO1-PO6 = peri-oral plates; $\mathrm{n}=$ nerve pore; $\mathrm{R} 1-\mathrm{R} 9$ = radial plates; $\mathrm{W}=$ wedge plates; $1-8=$ pericentral tegminal plates. Outlines of facets and food grooves dashed lines. $(\mathbf{1}, \mathbf{2})$ Redrawn from Bockelie (1979c, fig. 8c, 8b, respectively, p. 375). (3) Redrawn from Chauvel and le Menn (1979, p. 554, fig. 2e). (4) Redrawn from Lanc et al. (2015, p. 7, fig. 6). (5) Redrawn from Paul (1969, p. 193, fig. 2). (6) Redrawn from Frest (1975, p. 89, fig. 4a). (7) Redrawn from Frest (1975, p. 103, fig. 15). (8) Redrawn from Lanc et al. (2015, p. 5, fig. 3c).

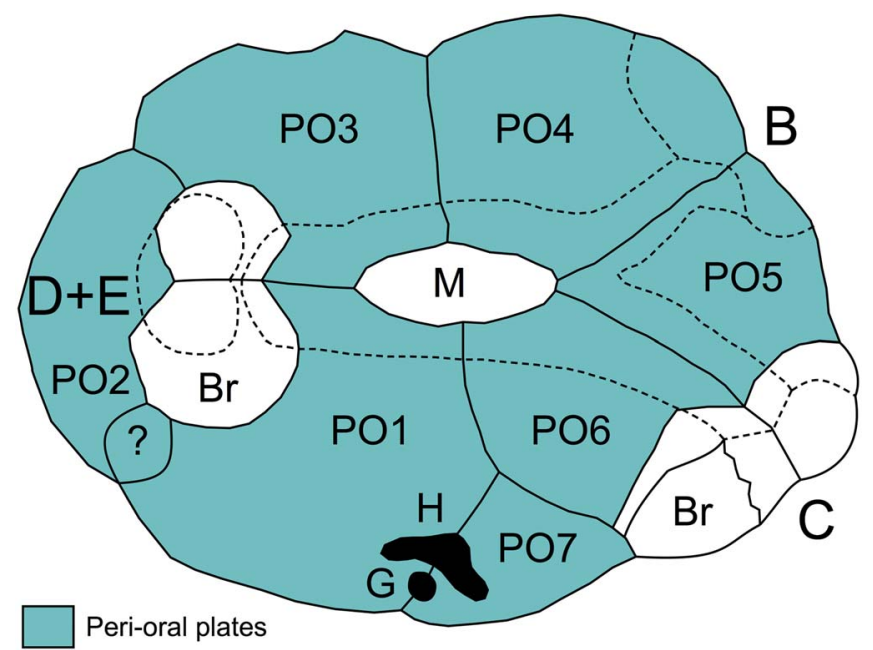

Figure 10. Ambulacra and oral plating of the glyptocystitoid rhombiferan Tyrridiocystis Broadhead and Strimple, 1978, to show three ambulacra, B, C, and $\mathrm{D}+\mathrm{E}$. Contrast with the aristocystitoid diploporite Triamara, which also has three ambulacra, but $\mathrm{B}+\mathrm{C}, \mathrm{D}$, and $\mathrm{E}$. $\mathrm{Br}=$ brachiolar plates; $\mathrm{G}=$ gonopore; $\mathrm{H}=$ hydropore; $\mathrm{M}=$ mouth; $\mathrm{PO} 1-\mathrm{PO} 7=$ peri-oral plates; $?=$ an additional plate between PO1 and PO2. Redrawn from Broadhead and Strimple (1978, p. 172, fig. 3a).

present. I suspect palates simply represent paedomorphic cessation of the introduction of new cover plates during growth. However, I would make a distinction between those peristome border systems (and palates) that are composed of six peri-oral plates (and six palatals) and those where only five peri-orals (and five palatals) occur. The former appear to characterize 'cystoid' groups, although the unusual diploporite Eumorphocystis Branson and Peck, 1940 apparently has five peri-orals. The latter are typical of crinoids.

Types B1 and B2 differ in having both circlets of plates in B1 and only the circum-orals in B2. However, here I think the proposed homology of the two circlets breaks down due to the positional test. In holocystitids, the peri-oral circlet forms the mouth frame and is surrounded by the circum-oral circlet. In Kammer et al.'s (2013) example of type B1 peristomial border system, the edrioasteroid Edriophus Bell, 1976b, the supposed circum-orals surround most of the mouth and the supposed peri-orals are more distal.

Mouth frames with paired ambulacral plates.—Brightonicystis (Fig. 5.4) bears humatipores and is a pentaradial holocystitid diploporite. It has ten plates forming the oral frame, plus an eleventh bearing the gonopore and forming part of the periproct frame. Large ambulacral facets are shared by two peri-orals and a circum-oral plate. The appendages that arose from these facets are unknown. The peristome bears the large 'oral pores' found in the oral plates of other holocystitid genera.

By contrast, hemicosmitoid rhombiferans have three primary ambulacra. Genera such as Hemicosmites (Fig. 9.1, 9.2) and Paracaryocrinites (Fig. 9.4) have three pairs of 'ambulacral' plates separated by two interradial plates (Hemicosmites) or a single plate in the $\mathrm{AB}$ and $\mathrm{EA}$ interradii 
plus three in the CD interradius (Paracaryocrinites) giving a total of 12 or 11 plates that contribute to the mouth frame. A gonopore occurs in the CD interradius of Paracaryocrinites. Large ambulacral facets are shared by two 'orals' and a lateral plate. The first few appendage plates are still attached in some species of Hemicosmites (see Bockelie, 1979b). They are

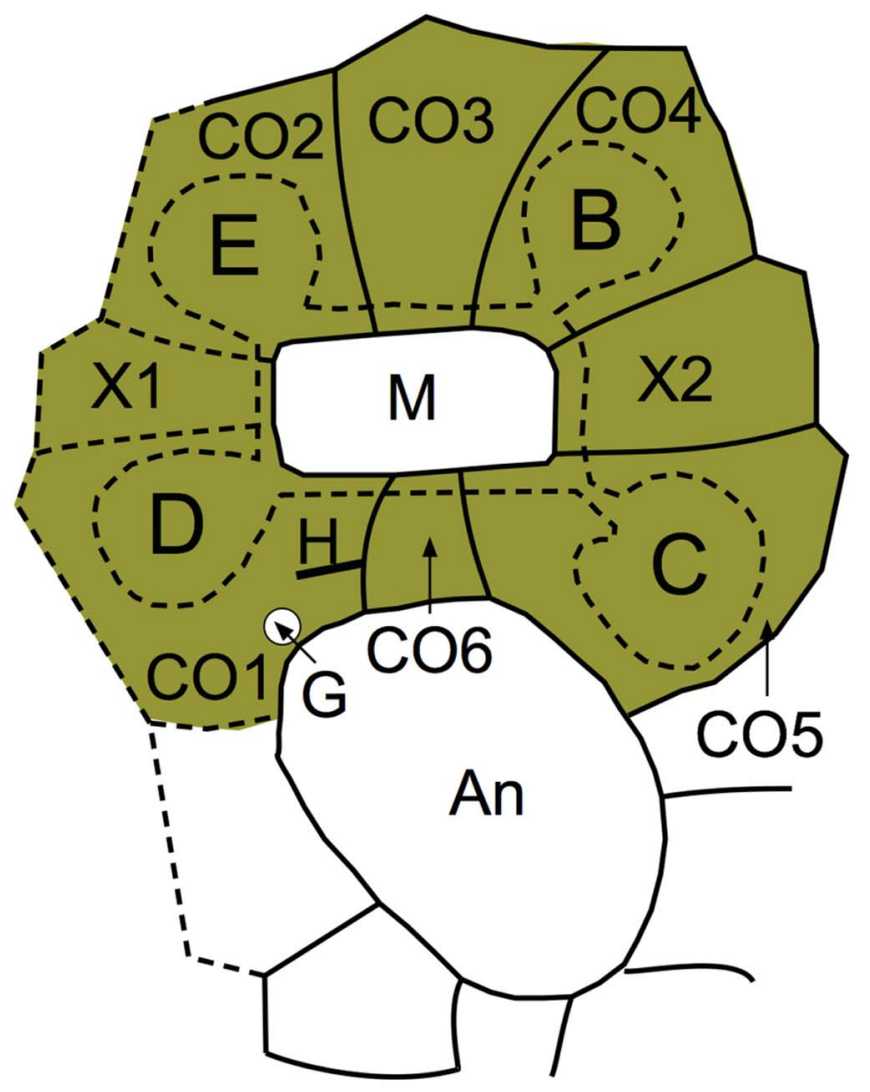

$\square$ Circum-oral plates

Figure 11. Ambulacra and oral plating in the parasphaeronitid diploporite Pachycystis Bockelie, 1984. Note that the mouth (M) is surrounded by eight circum-oral plates (CO1-CO6, X1, X2); the gonopore $(\mathrm{G})$ and hydropore $(\mathrm{H})$ occur in plate CO1. An - anus. Redrawn from Bockelie (1984, p. 15, fig. 11g). Dashed plate sutures inferred. biserial and the facets are assumed to have given rise to large arms with biserial brachioles alternating on either side, as in the related genus Caryocrinites (see Sprinkle, 1975; Lanc et al., 2015). The mouth is a three-rayed opening (Fig. 9.1, 9.4). Again, two plates from each ambulacrum contribute to the mouth frame. In Caryocrinites, the ambulacra branch (Fig. 9.6), but all three primary ambulacra do so in a similar manner. Thus, I do not think this is a three-fold ambulacral pattern developing into five ambulacra, but a fundamentally triradiate pattern in which all three ambulacra branch. Several species of Caryocrinites are characterized by six arm facets (Frest, 1975). In Figure 9, I have retained the plate names given by the original authors because it is very difficult to homologize individual plates in these taxa that have pairs of 'ambulacral' plates contributing to the oral frame with the groups discussed in the following where only a single 'ambulacral' plate contributes to the mouth border. Indeed, I believe that at least the hemicosmitoid genera lack any homologues of 'oral' plates in other 'cystoids.'

Mouth frames with single ambulacral plates.-Helicocystis Smith and Zamora, 2013 (Fig. 13) was regarded as the latest common ancestor of all pentaradial echinoderms and has seven interradial peri-orals, five of which align with the spiral ambulacra and two extra plates that occur in the CD interray associated with the gonopore. Similar patterns, with the oral frame composed of six peri-oral plates with or without a seventh plate associated with the hydropore and/or gonopore, are found repeatedly in 'cystoids' with five ambulacra (e.g., Figs. 3, 5, 8, 14). In some taxa with fewer than five ambulacra, the same basic pattern is retained (Figs. 10-12, 15) and was present in the recently described Sanducystis Zamora et al., in press. It is tempting to suggest that this is a fundamental pattern in 'cystoid' groups and other early echinoderms, as Sumrall (2010, 2015) has done.

Variations in this pattern of orals occur. For example, the 'eocrinoid' Rhopalocystis has six peri-orals around the mouth, which lack ambulacral facets (Fig. 8), as does Cryptocrinites von Buch, 1840 (Fig. 14.1), whereas only four of the peri-orals of glyptocystitoid rhombiferans form the mouth frame (Fig. 3).

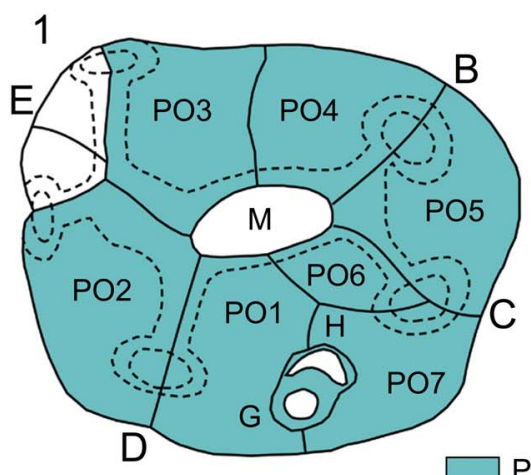

Peri-oral plates

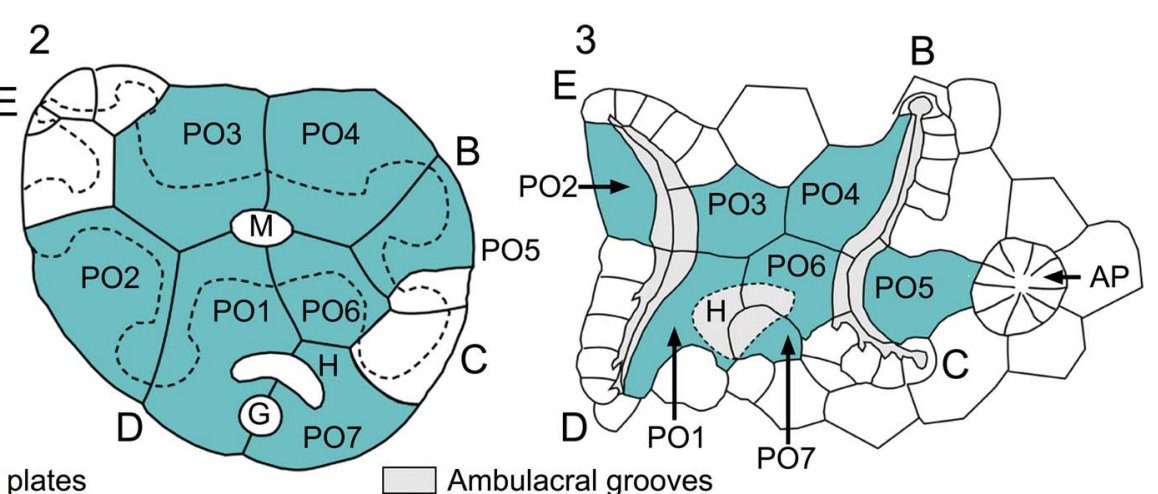

Figure 12. Ambulacra and oral plating in some 'cystoids' with four ambulacra. (1, 2) The glyptocystitoid rhombiferan Glansicystis Paul, 1967a. (3) The paracrinoid Bistomiacystis Sprinkle and Parsley, 1982. AP = anal pyramid; B-E = ambulacra; G = gonopore; H = hydropore; M = mouth; PO1-PO7 = peri-oral plates. (1, 2) Food grooves and ambulacral facets dotted. Although ambulacrum A is undeveloped, the full complement of seven peri-orals is present. (1, 2) Two examples of Glansicystis glans Paul, in Paul and Donovan (2011) with six and four plates framing the mouth, respectively. In Bistomiacystis, four of the peri-orals have overgrown the mouth. (1, 2) Redrawn from Paul and Donovan (2011, p. 448, fig. 14). (3) Redrawn from Sumrall and Deline (2009, p. 136, fig. 2). 
Glyptocystitoid peri-orals always share the first facet with an adjacent ambulacral plate (Figs. 3, 10) or with each other (Fig. 12.1, 12.2). The unusual diploporite Tristomiacystis Sumrall et al., 2009 (Fig. 14.2) and the paracrinoid Bistomiacystis Sprinkle and Parsley, 1982 (Fig. 12.3) have peri-orals that have grown over the ambulacral grooves producing multiple ambulacral orifices. The peri-orals of Tristomiacystis share ambulacral facets with the first ambulacral plates; those of Bistomiacystis do not. Finally, when ambulacra curve, ambulacral facets are always aligned on the outside of the curve as in the gomphocystitid diploporite Celticystis Bockelie 1979a (Fig. 14.3) and the paracrinoid Bistomiacystis (Fig. 12.3).

In sphaeronitid (Fig. 5.1-5.3) and parasphaeronitid diploporites (Fig. 11), five of the 'orals' are radial in position as are those of the 'eocrinoid' Lichenoides Barrande, 1846. Here these are distinguished as circum-orals, and they occur in a mouth frame of six plates in sphaeronitids, but eight in parasphaeronitids (Fig. 11). It is believed these circum-orals are homologous with

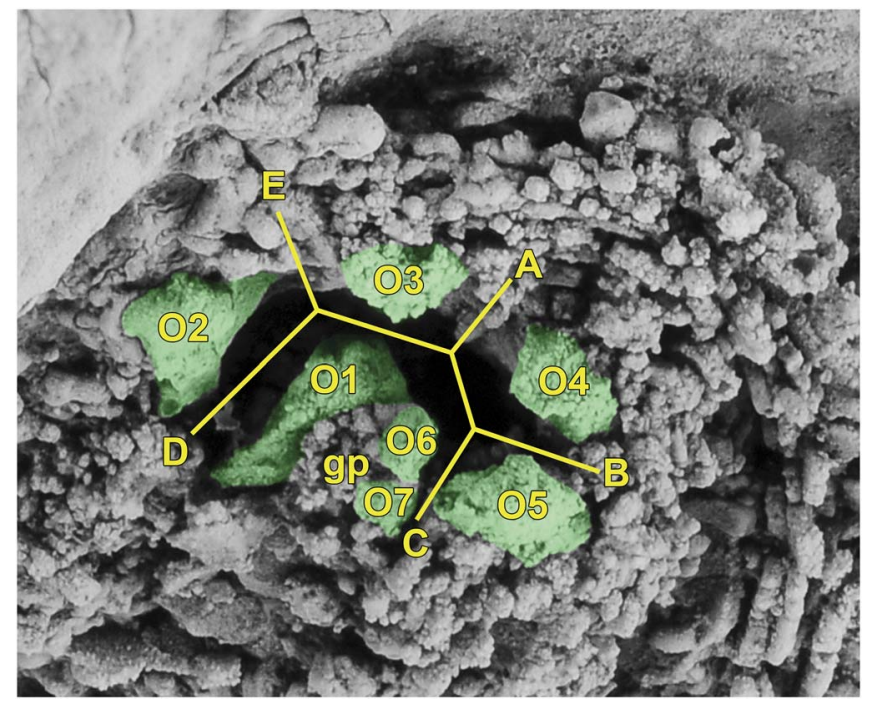

Figure 13. Oral area of Helicocystis Smith and Zamora, 2013, to show seven oral plates and spiral ambulacra (above and right). the outer circlet of plates in holocystitids, originally called facetals by Paul (1971). In the holocystitid Pustulocystis Paul, 1971, there are six facetal plates, whereas in Holocystites Hall, 1864, Trematocystis, and Pentacystis Paul, 1971, there are eight (Fig. 5.5, 5.6). By contrast, aristocystitid diploporites have at least eight plates surrounding the mouth (Fig. 7), which are here interpreted as a mixture of four peri-orals and four circum-orals.

Recently, Sheffield and Sumrall (2015) have discussed oral plate homology in holocystitid diploporites. The paper contains some taxonomic errors; Trematocystis was described by Jaekel (1899) not Miller (1878), Pustulocystis by Paul (1971) not Miller (1891), and Pentacystis gibsoni by Frest and Strimple (in Frest et al., 2011) not by Paul, 1971. More important, Sheffield and Sumrall (2015) suggest two new interpretations of the oral plating in the Holocystitidae. First, they suggest that the first two circlets surrounding the mouth consist of seven orals and seven facetals, not six and eight as originally suggested by Paul (1971, p. 13). Then they suggest that Pentacystis possessed a complete oral circlet with six plates surrounding the mouth, but that these were lost taphonomically. The first suggestion is not controversial, especially given the large number of early echinoderms that are now known to have the basic pattern of six peri-orals forming the mouth frame, plus a seventh often bearing the gonopore in the CD interray.

The suggestion that Pentacystis originally had the six orals surrounding the mouth is attractive. It would certainly make the anatomy of almost all holocystitid genera more consistent. In support of this interpretation, the type species Pentacystis simplex Paul, 1971, which was originally thought to lack all six plates, lacks the distinctive oral pores that usually line the peristome frame in other holocystitids, suggesting the six perioral plates are indeed missing. However, Frest and Strimple (in Frest et al., 2011, p. 89, fig. 46c) illustrated a specimen of Osgoodicystis cooperi with just the two orals in the CD interray and oral pores developed on the five 'facetals' (equivalent to CO2-4, X1-2 in Fig. 5.5) that complete the oral frame. Sheffield and Sumrall (2015, p. 161, fig. 1c) illustrate a specimen of Pentacystis gibsoni in which they interpret some loose plates in the $\mathrm{E}, \mathrm{A}$, and $\mathrm{B}$ radii as displaced peri-orals. It is difficult to see
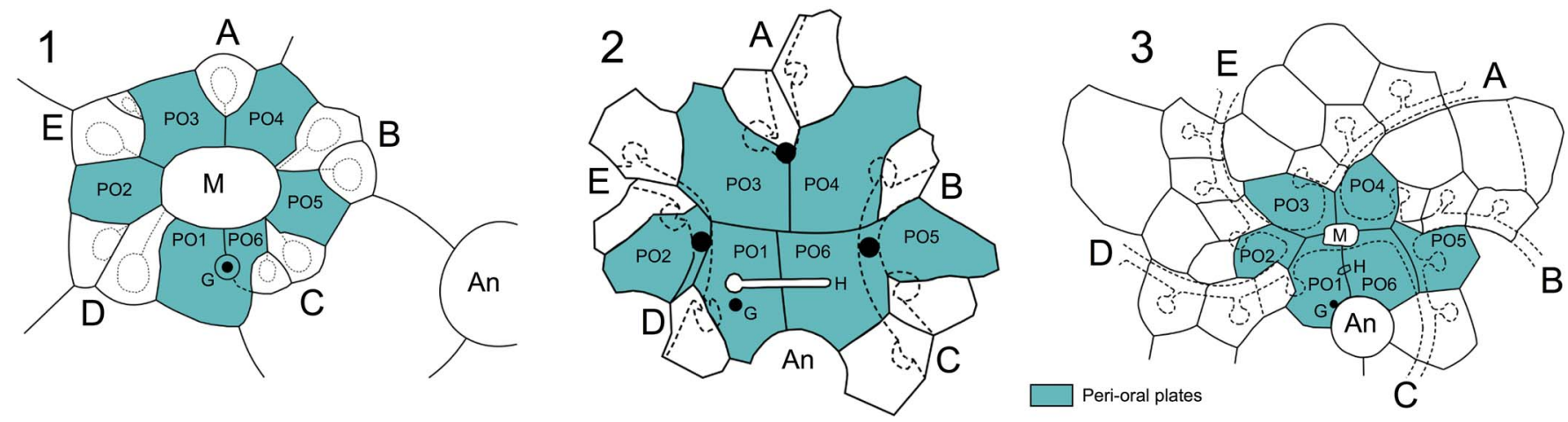

Figure 14. Ambulacra and oral plating in some pentameral 'cystoids.' (1) The cryptocrinitid Cryptocrinites von Buch, 1840. (2) The protocrinitid diploporite Tristomiacystis Sumrall et al., 2009. (3) The gomphocystitid diploporite Celticystis Bockelie, 1979a. A-E = ambulacra; An = anus; $\mathrm{G}=$ gonopore; $\mathrm{H}=$ hydropore; $\mathrm{M}=$ mouth; PO1-PO6 = peri-oral plates. Food grooves and ambulacral facets dotted. Three ambulacral orifices of Tristomiacystis black. (1) Redrawn from Bockelie (1981b, p. 139, fig, 10b). (2) Redrawn from Sumrall et al. (2009, p. 745, fig. 5.1). (3) Redrawn from Bockelie (1979a, p. 160, fig. 5a). The larger, presumed first ambulacral facet in Cryptocrinites is to the left (counterclockwise) in each ambulacrum; the peri-orals lack facets; and the anus lies in the BC interray. In Tristomiacystis, the first facets are to the left and shared by a peri-oral plate and an ambulacral plate; four of the peri-orals have overgrown the mouth. Celticystis has all facets to the left of the ambulacra, and the first facets are shared by a peri-oral and an ambulacral plate except in ambulacrum C. 

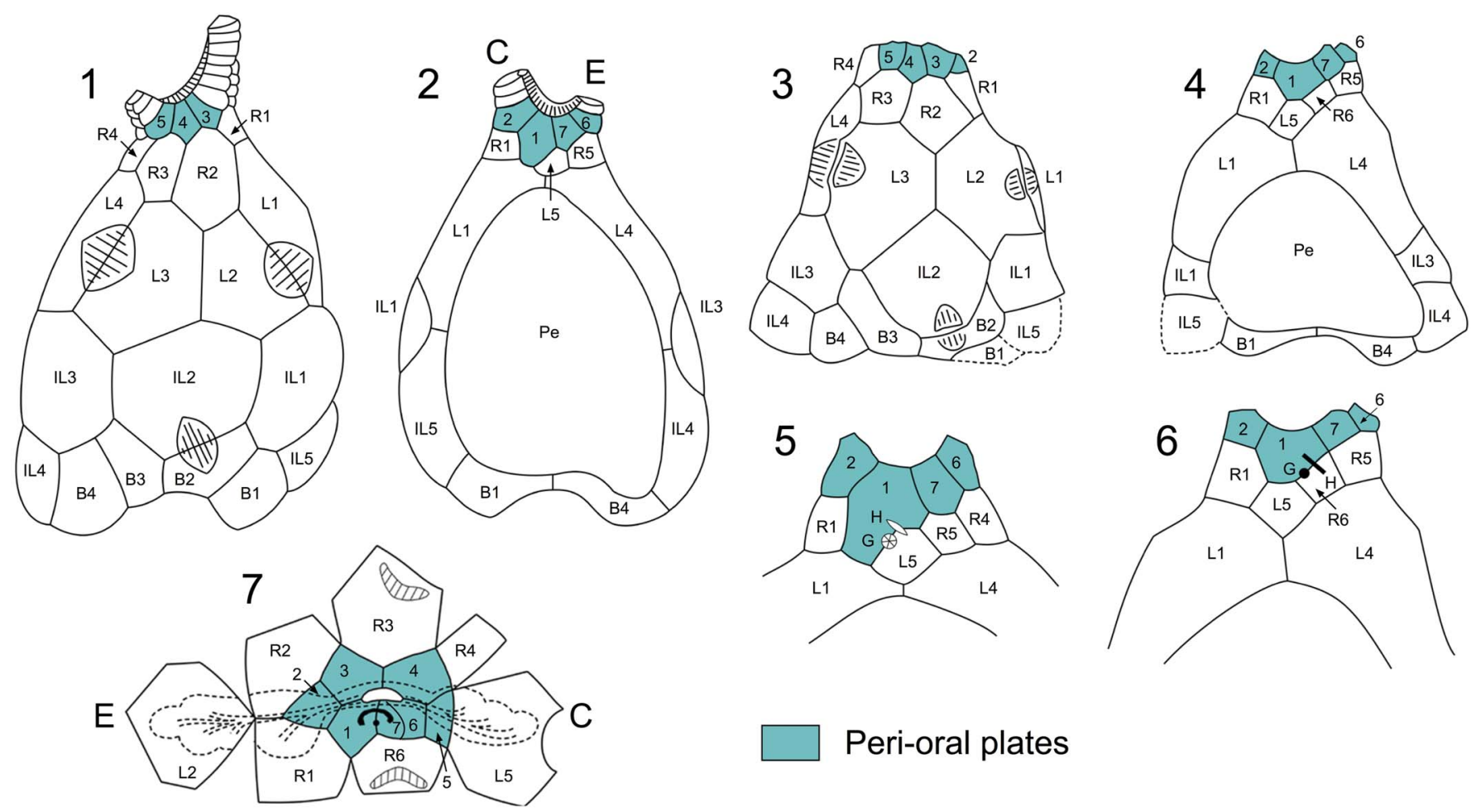

Figure 15. Ambulacra and oral plating in some glyptocystitoid rhombiferan 'cystoids' with two ambulacra. $(\mathbf{1}, \mathbf{2}, \mathbf{5})$ Pleurocystites Billings, 1854. (3, 4, 6) Praepleurocystis Paul, 1967b. (7) Schizocystis Jaekel, 1895. B1-B4 = basal plates; C and E = ambulacra; G = gonopore; H = hydropore; IL1-IL5 = infralateral plates; L1-L5 = lateral plates; Pe = enlarged periproct of pleurocystitids; R1-R6 = radial plates; $1-7=$ peri-oral plates. Although only two ambulacra occur, the full complement of seven peri-oral plates remains. See text for further explanation of thecal plating in the pleurocystitids. (1-4) Redrawn from Paul (1984, p. 119, fig. 76); (5, 6) from Paul (1967b, p. 113, figs. 8, 9), respectively; (7) from Kesling (1968a, p. S185, fig. 89, 1b). The ambulacral facets in Schizocystis (7) are largely to the left in both ambulacra.

how these plates could have become detached from the oral frame yet remained only slightly displaced. The theca would have had to be almost completely filled with sediment for this to happen, otherwise the plates would have fallen into the empty theca or been carried away by currents. In addition, I know of no other diploporite (or 'cystoid') taxon that has completely lost one circlet of plates but is otherwise undamaged. The mouth of $P$. simplex is rounded, not angular as one would expect if a circlet of angular plates were missing. In addition, Frest and Strimple (2015) cited multiple specimens of the new species they erected, so this loss of peri-orals apparently occurred repeatedly. I have not examined any of the thousands of additional holocystitids that have been found at Napoleon, Indiana, since the expansion of the quarry there (see Frest et al., 2011, p. 2). I think Sheffield and Sumrall's (2015) suggestion needs further examination. One thing can be said: the oral frame was extremely small in Pentacystis and Osgoodicystis. In both genera, if the oral cover plates were preserved, the oral frame plates would be almost completely hidden.

Mouth frames with five orals.-In contrast to the 'cystoids' described in the preceding section, others appear consistently to have had five peri-orals. This is true of caryocystitid rhombiferans (Fig. 6) and the unique hemicosmitoid rhombiferan Thomacystis Paul, 1969 (Fig. 9.5). Five peri-orals also occur in the diploporite genus Eumorphocystis, which has triserial erect ambulacra among other unique features. In these cases, five peri-orals arose independently. Even in examples of caryocystitids with four ambulacra (e.g., Fig. 6.3, 6.6) there are two peri-oral plates in the $\mathrm{CD}$ interradius. Ambulacrum A is never developed, although all four other ambulacra may divide to produce two appendages per ambulacrum in Echinosphaerites (e.g., Bockelie, 1981a, p. 199, fig. 10; Paul, 1997, p. 169, fig. 102). Thus, in caryocystitids (Fig. 6) and Thomacystis (Fig. 9.5), the five peri-orals present are interpreted as PO1, $\mathrm{PO} 2$, and $\mathrm{PO} 4-\mathrm{PO} 6$ because $\mathrm{PO} 3$ is associated with the missing ambulacrum A. However, in Eumorphocystis, there is apparently a single oral in the CD interradius, and the five orals are here interpreted as PO1-PO5.

This last point may be significant. Glyptocystitoid rhombiferans may have from one to five ambulacra, and in some genera, e.g., Callocystites Hall, 1852, the ambulacra may branch (Paul, 2015), yet all seven peri-orals are always present as far as is known. By contrast, in 'cystoid' genera with five peri-orals, it seems possible to distinguish which of the peri-orals is missing. Thus, if peri-orals are primary ambulacral plates, then at least in glyptocystitoids all the peri-orals were consistently developed before the growth of an ambulacrum was 'turned off.' However, in caryocystitids and Thomacystis, PO3 was lost along with the associated ambulacrum A, whereas in other 'cystoids' with five peri-oral plates, it was the 'extra' peri-oral in the CD interray (PO6) that was lost.

As far as is known, paracrinoids commonly have five plates associated with the mouth (Fig. 16), although Parsley (1978, p. 474, fig. 1) illustrated a specimen of Comarocystites Billings, 1854 , with a very small mouth surrounded by just three 'orals.' 

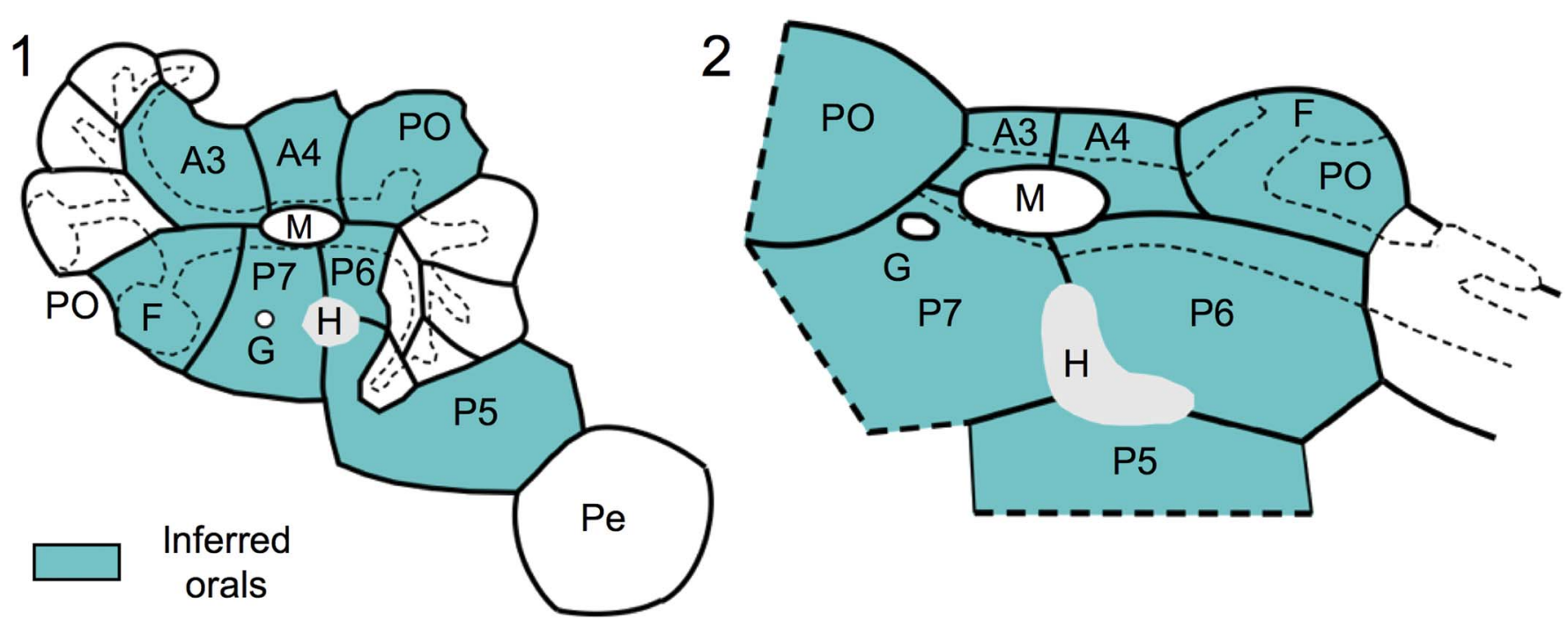

Figure 16. Oral regions of paracrinoids (1) Canadocystis Jaekel, 1900 and (2) Platycystites Miller, 1889. A3, A4 = 'anterior' plates; F = pinnule facet; $\mathrm{G}=$ gonopore; $\mathrm{H}=$ hydropore; $\mathrm{M}=$ mouth; $\mathrm{P} 5-\mathrm{P} 7=$ 'posterior' plates; Pe = periproct; $\mathrm{PO}=$ primary ossicle of recumbent arm. Labeling follows Parsley and Mintz, 1975. (1), Redrawn from Kesling, 1968b (p. S280, fig. 162.2g). (2) Redrawn from Parsley and Mintz, 1975 (p. 65, fig. 5).

Many paracrinoids have just two ambulacra, which may define two faces currently referred to as 'anterior' and 'posterior' (see Parsley and Mintz, 1975; Frest and Strimple, 1976; Frest et al., 1976; Parsley, 1982b). Two plates of the anterior face (A3, A4) and two of the posterior face (P6, P7) usually frame the mouth (Fig. 16.2). The gonopore consistently occurs in plate P7, and the hydropore occurs at the triple junction between plates P5-P7 (Fig. 16.2). This arrangement is present in globular genera such as Canadocystis Jaekel, 1900 (Fig. 16.1). Insofar as it can be determined, these plates are interradial and are here accepted as peri-orals. An unusual feature of many paracrinoids is that the first ambulacral facet in both ambulacra is significantly larger than subsequent facets. If one includes these two ambulacral plates (PO in Fig. 16), then many paracrinoids have seven periorals. Unfortunately, not all these peri-orals can be homologous with the seven 'orals' identified in Bistomiacystis (Fig. 12.3).

\section{Ambulacral structure}

This is probably the part of this paper where we have the least information. In the taphonomy of 'cystoids,' it appears that after death, loss of erect ambulacral structures occurred first. Furthermore, the loss was commonly at the junction with the theca, so that entire structures were lost immediately rather than being degraded bit by bit from their tips. For example, in the Diploporita, no sphaeronitid is known with ambulacral appendages preserved, and in the Holocystitidae, Frest and Strimple have described a handful of specimens in which the first ambulacral plate is preserved in some ambulacra (Frest et al., 2011, p. 31, pl. 4), where the plates are all uniserial. Chauvel (1977) described four or five examples in the Aristocystitidae in which any evidence of brachioles is preserved. Thus, in this paper, unknown ambulacral structures are referred to as 'appendages.' Historically, the most significant feature of ambulacral structures was whether the plating was uniserial or biserial. Here, terminal uniserial structures are called 'pinnules,' biserial structures are called 'brachioles,' and complex,

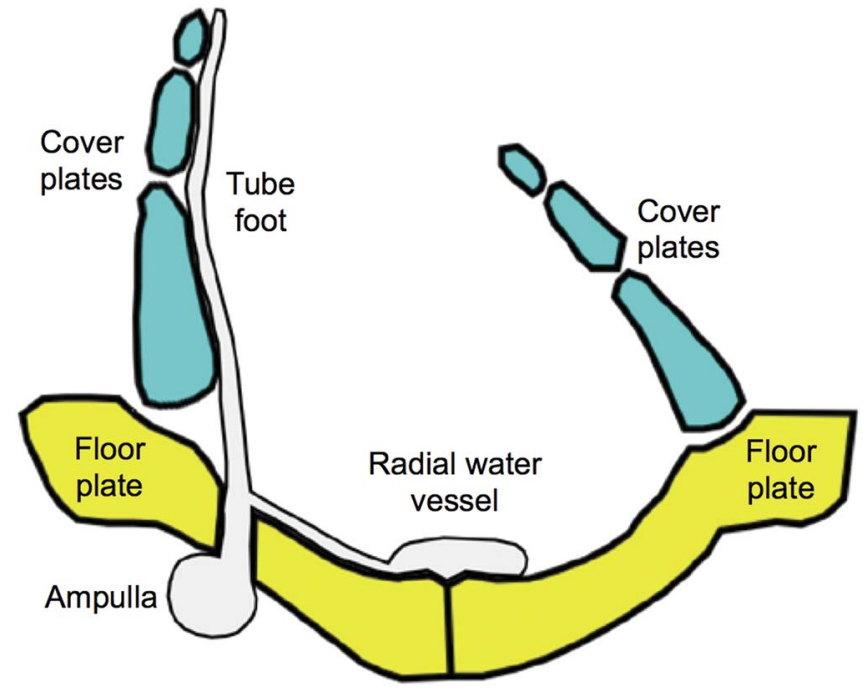

Figure 17. Ambulacral structure and inferred water vascular system in helicoplacoids to show that both flooring and cover plates have the same topological position relative to the radial water vessel and tube feet, respectively. Redrawn from Paul and Smith (1984, fig. 4D).

branched structures are called 'arms' without inferring any phylogenetic implications. All three may be erect or recumbent on the theca (Supplementary material, Table 3). In addition, whatever the ambulacral plating, they can be developed in three positions. Those forming part of the thecal wall are here referred to as 'mural.' Those developed outside the theca are 'exothecal' and may be either erect or recumbent on the thecal surface. In the latter case, pathways develop on thecal plate surfaces to accommodate the ambulacral structures. Such ambulacral structures have frequently been described as 'epithecal,' but this term has been used for both mural and recumbent structures in the past and is best abandoned.

All parts of the ambulacral system including flooring and cover plates bear the same topological relationship to the inferred radial water vessels or tube feet (Fig. 17) and so can be 
regarded as homologous. In effect, this is restating the EAT in a different way-all such plates are part of the axial skeleton and therefore homologous at that level of homology. However, some oral cover plates were added at intermediate positions during growth rather than always terminally (Fig. 3). For example, Sumrall (2010, p. 270, fig. 1) has identified five cover plates at the interrays between the ambulacra as "primary oral cover plates' in the glytocystitoid rhombiferan Lepadocystis. I prefer to include a second in the CD interray, making six primary oral cover plates in all (Fig. 3), but either way, if these cover plates were the first to be secreted then the other oral cover plates between primaries 2 and 5 in Figure 3 were added later and could not have been added terminally as the ambulacra grew. Similar patterns occur in the oral cover plates of edrioasteroids (Bell, 1976a, b). This is not an anomaly under the EAT, as cover plates have not been considered to comply universally with the ocular plate rule of exclusively terminal addition (see, for example, Mooi et al., 2005, p. 546).

Modern crinoid ambulacra differ from those of all other living classes in lacking a tube foot/ampulla system and in having tube feet arranged in triplets (Nichols, 1960) (Fig. 18). They also lack calcified cover plates but have lappets alternately on either side of the food groove instead. When feeding, the long tube feet are extended horizontally, between the lappets (Fig. 18.3). The intermediate and short tube feet are attached to the lappets proximally and extend at different angles to the horizontal (Fig. 18.2, 18.3). When the latter two bend to deposit food in the food groove, they move the lappets. There is, thus, a 1:1 relationship between tube-feet triplets and lappets. It is possible that a similar 1:1 relationship occurred between 'cystoid' tube feet and cover plates or cover plate sets. It is equally possible that the structure of modern crinoid tube feet is a post-Paleozoic innovation and that such uniformitarian arguments do not apply to the Paleozoic.

Sumrall $(2008,2010)$ used the ambulacra of glyptocystitoid rhombiferans as typical in developing his universal elemental homology (UEH) model, so it is appropriate to consider

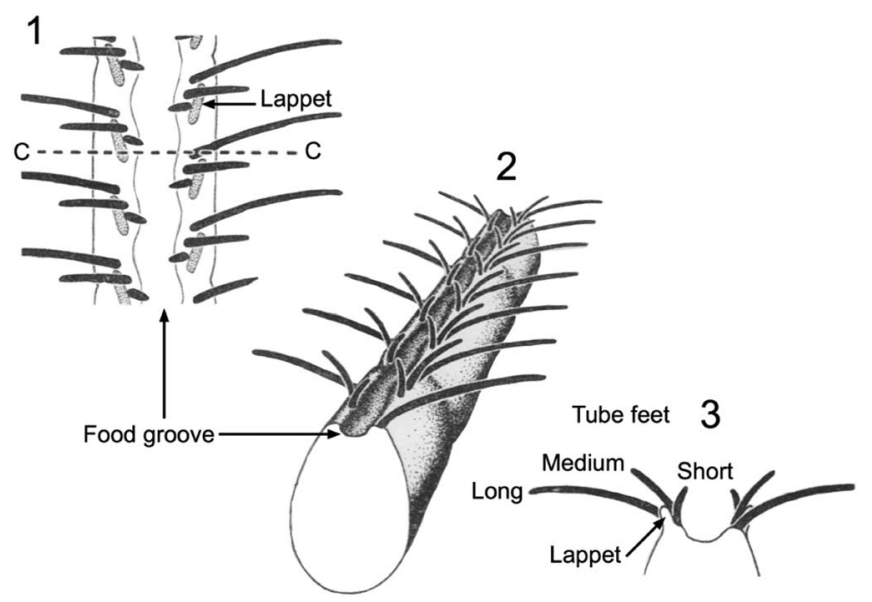

Figure 18. Water vascular system in a pinnule of the Recent comatilid crinoid Antedon. (1) Ventral view showing the triplets of tube feet (black) and their relationship to the lappets. $\mathrm{C}-\mathrm{C}=$ position of the cross section in (3). (2) Oblique ventral view. (3) Cross section to show orientation of tube feet with respect to the long axis of a pinnule. Redrawn from Nichols (1960, fig. 1). glyptocystitoid ambulacral structure as a whole (Fig. 3). In glyptocystitoid rhombiferans, the first, horseshoe-shaped, brachiole facet is developed to the left (as viewed in the direction of growth) in all ambulacra (Fig. 3) and is shared by one of the peri-orals (PO1-PO5) and the plates labeled L ("first left ambulacral floor plates" of Sumrall and Waters, 2012). Thereafter, each brachiole facet is supported by a smaller adoral ambulacral flooring plate and a larger distal flooring plate. Here, I suggest these pairings are homologous and represent the first pair of brachiolar plates modified to form a peri-oral plus an L plate or pairs of ambulacral flooring plates. Glyptocystitoids with all five ambulacra have an unusual arrangement in which ambulacra B and D have the first two brachioles to the left, and thereafter brachioles alternate right and left to the tip of the ambulacrum. In ambulacra A, C, and E, only the first brachiole lies to the left of the ambulacrum, and brachioles alternate regularly throughout these ambulacra (Fig. 3). Irrespective of this unexpected 'B D different' pattern of primary brachioles in glyptocystitoids, in early forms the ambulacral flooring plates form part of the thecal wall. When extensive ambulacra are developed, as in the cheirocrinid Coronocystis Paul, 1972, clefts develop in the extended radial plates to accommodate the ambulacra. Furthermore, the oral frame is composed of the first ambulacral plates secreted on the left side of all five ambulacra plus a sixth (PO6) in the CD interray. Brachioles are biserial, and in extensive ambulacra the main trunk is composed of a double biseries of flooring plates. Here, this structure is interpreted as resulting from the first pair of brachiolar plates on either side being modified as flooring plates. A similar structure occurs in the main trunk of the erect arms of the hemicosmitoid rhombiferan Caryocrinites Say, 1825 (see Sprinkle, 1975; Lanc et al., 2015) and the recumbent ambulacra of blastoids (Beaver, 1968, p. S322, fig. 190).

Main ambulacral trunks occasionally branch in the glyptocystitoid families Callocystitidae and Glyptocystitidae. In Callocystites and Coelocystis Schuchert, 1903 (Callocystitidae), the branching is equal (Paul, 2015), whereas in Sphaerocystites Hall, 1859, Strobilocystites White, 1876 (Callocystitidae), and Hesperocystis Sinclair, 1945 (Glyptocystitidae) the branching is unequal (Sprinkle, 1982a; Paul, 2015).

The suggestion that peri-orals and L plates are basically modified first brachiolar plates can be tested by seeing whether a similar pattern can be found in other groups of 'cystoids' besides glyptocystitoids and the hemicosmitoid Caryocrinites. The eocrinoid Rhopalocystis (Fig. 8) has peri-orals that do not bear or share brachiole facets. Thereafter, a simple biserial set of mural ambulacral flooring plates bear brachiole facets contained entirely within the individual plates. Such an ambulacral structure could be derived in an analogous way to the ambulacral structure of glyptocystitoids if the appendages were pinnules and the first pinnular plates were modified as ambulacral flooring plates. Unfortunately, Rhopalocystis has biserial brachioles (Ubaghs, 1963, p. 36, pl. 1, fig. 4).

Recumbent biserial ambulacra occur in the palaeocystitids Ulrichocystis Bassler, 1950, and Bromidocystis Sprinkle, $1982 \mathrm{~b}$, with each ambulacral facet confined to a single flooring plate (Paul, 1988; Sprinkle, 1982b). In Bromidocystis, the periorals lack ambulacral facets. Ulrichocystis had three ambulacra with unknown appendages, whereas Bromidocystis had five 
ambulacra and recumbent brachioles (Sprinkle, 1982b, p. 290, fig. 72i). Rhopalocystis and Bromidocystis alone are enough to show that having a facet confined to a single plate does not indicate the appendages that arose from the facet were uniserial. Equally, the coronate genera Stephanocrinus Conrad, 1842 and Cupulocorona Donovan and Paul, 1985 are known to have had isotomously branched erect biserial arms (Fay, 1962; Brett et al., 1983), but the first plate of each ambulacrum is uniserial and analogous to a crinoid axilliary plate (Donovan and Paul, 1985, p. 528). Thus, it seems that biserial brachioles can arise from one or a pair of flooring plates in 'cystoids.'

Erect biserial arms are known in the eocrinoids Trachelocrinus Sprinkle, 1973 and Bockia Bockelie, 1981b. Trachelocrinus is unique in having lateral brachioles that branch off every third trunk plate (Sprinkle, 1973, p. 125). Bockia has essentially the same structure as Rhopalocystis only with erect arms. Biserial brachioles arise alternately along the biserial main ambulacral trunk (Bockelie, 1981b, p. 129, fig. 2g, j). Both Bockia and Trachelocrinus have erect arms arising from an oral prominence, which Bockelie (1981b, fig. 3a, b) thought was composed of seven peri-orals in Bockia.

Undoubted uniserial ambulacra (main trunk and pinnules) occur in paracrinoids and may be erect (e.g., Comarocystites, see Parsley and Mintz, 1975, pl. 1, figs. 2, 3) or recumbent (e.g., Sinclairocystis, see Parsley, 1982b). Most paracrinoids have recumbent ambulacra in which the pinnules arise exclusively on one side of the ambulacrum, usually the left side, but the right in the unusual paracrinoid Bistomiacystis (Sprinkle and Parsley, 1982). Most commonly, paracrinoids have just two recumbent ambulacra, but sometimes one or the other branches. Both ambulacra are curved clockwise in Canadocystis, giving an S-shaped pattern (see Parsley and Mintz, 1975, pl. 10, fig. 9, pl. 11, figs. 14,15). Clockwise ambulacra have their left sides on the outside of the curve, and ambulacral facets are confined to the outside of the curve. Thus, Bistomiacystis has two pairs of ambulacra curved in a counterclockwise manner (Sprinkle and Parsley, 1982, p. 225, fig. 60), and this probably explains why it has its facets confined to the right side of each ambulacrum. The flattened eocrinoid Haimacystis Sumrall et al., 2001, has only two ambulacra curved in a rough semicircle, apparently composed of biserial trunk plates possibly with biserial brachioles arising from the outer edge of the curved ambulacra (Sumrall et al., 2001, p. 988, fig. 2.2, p. 990, fig. 4.3). Thus, one ambulacrum has brachioles exclusively to the left side and the other exclusively to the right. An oddity of paracrinoid ambulacra is that in some taxa, the first pinnule on each ambulacrum is disproportionately large (see, for example, Parsley and Mintz, 1975, pl. 3, fig. 5, pl. 7, figs. 14, 15). Finally, Malocystites murchisoni Billings, 1858, is unique among paracrinoids in having recumbent pinnules (Parsley and Mintz, 1975, p. 86).

Rozhnov $(2012,2015)$ has recently summarized available information on two possible paracrinoid genera from the Baltic region. Heckerites Rozhnov, 1987 has two recumbent biserial ambulacra, which are said to form part of the thecal wall, with biserial brachioles arising from only some of the flooring plates (Rozhnov, 2012, p. 310, 311, fig. 3). Similarly, Achradocystites has erect biserial arms with alternating biserial brachioles. Superficially, Heckerites resembles the North American paracrinoid Amygdalocystites Billings, 1854, and the erect ambulacra of Achradocystites resemble those of the North American genus Comarocystites, but both North American genera have uniserial ambulacra bearing pinnules on one side only. Thus, it seems unlikely that either Heckerites or Achradocystites has close affinities with the North American paracrinoids.

Diploporite 'cystoids' include yet other ambulacral structures that pose problems in recognizing homologies. First, sphaeronitid diploporites have radial circum-orals, rather than the interradial peri-orals of most other 'cystoids.' In many genera, the entire ambulacra are confined to these radial circumorals and consist of one or more epithecal food grooves, which end in small (about $1 \mathrm{~mm}$ or less) facets. The appendages that arose from them remain entirely unknown. Two significant variations in this basic pattern occur. First, in four sphaeronitid genera, Codiacystis Jaekel, 1899, Tholocystis Chauvel, 1941, Herpetocystis Termier and Termier, 1972, and Finitiporus Frest and Strimple (in Frest et al., 2011), two narrow food grooves leave the edges of the mouth and branch in opposite directions to form a palisade of ambulacral facets surrounding the mouth (see Frest et al., 2011, p. 32, fig. 19). Frest and Strimple described such ambulacra as 'epipanniculate' and assigned them to a new subfamily, Herpetocystinae (Frest et al., 2011, p. 59, table 19, p. 62), although Termier and Termier (1972) had previously erected a family Herpetocystidae.

Second, in some species of Eucystis Angelin, 1878 and all species of Glyptosphaerites Müller, 1854, some food grooves extend over the theca to plates beyond the circum-oral circlet. The arrangement of these longer food grooves was apparently random, especially in Glyptosphaerites. Regnéll (1945, pl. 9, fig. 5) illustrated a specimen with two parallel ambulacral branches that produce two facets each on three plates. Similarly, Kesling (1968a, p. S235, fig. 135, 1a, 1b) illustrated ambulacra in which some thecal plates bear two ambulacral facets, whereas others bear the food groove but no facets. Apparently, the thecal plates existed before the ambulacral grooves extended over them and developed facets. If so, thecal plates bearing parts of the food grooves and facets cannot be considered to be 'ambulacral plates' or even part of the axial skeleton. Furthermore, the ambulacral grooves bear no trace of any cover plates.

Other diploporites, such as Protocrinites Eichwald, 1840 and Dactylocystis Jaekel, 1899, have a thecal structure with a regular arrangement of ambulacral plates. In Protocrinites, the food grooves extend down the theca and give rise to lateral branches alternately, which end in a single facet confined to a single thecal plate (Bockelie, 1984, p. 28, fig. 16). Thus, the ambulacra appear to be composed of regularly arranged biserial thecal plates. Bockelie (1984, fig. 16) even showed that there was a growth zone where thecal plates were added above the basal two circlets of plates, which coincided with the tips of the five ambulacra. The facets give rise to erect biserial brachioles despite being confined to a single thecal plate. Both main ambulacral grooves and brachioles are furnished with cover plates. Dactylocystis shows an even more regular arrangement in which narrow ambulacra are composed of regularly alternating plates that bear a single facet and all the diplopores. No interradial plates bear pores (Kesling, 1968a, fig. 146, 4a, b).

The Gomphocystitidae bear spiral ambulacra that coil in a clockwise manner so appendages arise from the left side only. 
The ambulacra are effectively uniserial, being composed of a single series of plates with one short lateral food groove and facet confined to each plate. Bockelie (1979a, p. 160, fig. 5a) showed an unexpected arrangement in Celticystis Bockelie, 1979a, in which the first ambulacral facet was shared between a peri-oral and the first ambulacral plate in ambulacra A, B, D, and $\mathrm{E}$, but the first facet was confined to the first ambulacral plate in ambulacrum $\mathrm{C}$. The figure is a partial reconstruction from two specimens, so perhaps one should not read too much into the anomalous ambulacrum $\mathrm{C}$. Another interesting feature of the ambulacra of Celticystis is that over most of the theca the ambulacral plates form part of the thecal wall, but on reaching the basal circlet of plates by which the diploporites were attached to the substrate in life, the ambulacrals lie on top of the 'basals.' The tips of the ambulacra are recumbent (Bockelie, 1979a, p. 161, fig. 6). Uniserial, mural ambulacra also occur in Gomphocystites Hall, 1864 (Bockelie, 1979a, p. 165, fig. 11). No ambulacral appendages of gomphocystitid diploporites have been found.

Finally, among diploporites with arms as defined here, Eumorphocystis has the most complex ambulacral structure (Parsley, 1982a; Paul and Fone, 1997). The mouth is surrounded by five interradial peri-orals of which the one in the $\mathrm{CD}$ interray is the largest but shows no signs of being double. A structure interpreted as the hydropore by Parsley (1982a, p. 283) occurs adjacent to the $\mathrm{CD}$ peri-oral. Five ambulacra radiate from the mouth with alternate biserial flooring plates that bear undoubted brachiole facets. The flooring plates form part of the thecal wall. At the edge of the oral surface, the ambulacra become exothecal with an erect, triserial main trunk, which gives rise laterally to erect pinnules. Paul and Fone (1997, p. 159) questioned whether the lateral structures on the free arms were truly pinnules because no illustration showed the critical aboral surfaces of the pinnular plates where a median suture might be expected if the appendages were brachioles. However, Parsley (1982a, p. 284, pl. 36, fig. 15) does show one pinnule in adoral view that clearly has aligned sutures on opposite sides of the food groove. This is compatible with pinnular structure, and so I now accept Parsley's description in full. Thus, Eumorphocystis combines almost all possible structures in its ambulacra. It has simple biserial floor plates that form part of the thecal wall, erect biserial brachioles that arise from a facet within a single flooring plate, and erect triserial arm trunks from which uniserial pinnules arise alternately. The facets from which the erect arms arise are each composed of five thecal and ambulacral plates.

In the British species Eumorphocystis coxi Paul and Fone, 1997, the ratio of aboral to lateral arm plates was exactly $2: 1$ (Paul and Fone, 1997, p. 157). Parsley (1982a, p. 286) stated that this ratio varied from $2.5: 1$ proximally to $1.5: 1$ distally in the type species E. multiporata Branson and Peck, 1940. However, Parsley's illustrations (1982a, p. 284, pl. 36, figs. 15, 18) show a regular arrangement, and in the text (p. 286) he stated 'every other bracing plate [my aboral arm plate] inserting slightly into am series [my lateral arm plates].' Thus, it seems a fairly regular arrangement of two aboral arm plates per lateral arm plate occurred in E. multiporata too. If one seeks a possible homologue of the erect arm structure in Eumorpholocystis, the biserial, alternate, lateral arm plates make sense as first pinnulars modified to become flooring plates in an analogous manner to the structure of Caryocrinites arms, in which the trunk plates can be considered as the first pair of brachiolars modified as trunk plates. However, suggesting a homologue of the aboral series of arm plates in the triserial arm of Eumorphocystis is more difficult.

Finally, care is required when interpreting the structure of entire appendages from only the basal parts. Sprinkle (1973, p. 110) described the brachioles of the eocrinoid Lichenoides as possibly starting with a single plate, then having a few biserial opposite plates, and finally, through most of the length of the brachioles, having normal, biserial, alternate plating. He also illustrated brachioles in the flattened eocrinoid Petalocystites Sprinkle, 1973, with the first five to 10 proximal brachiolar plates biserial opposite but more distal ones biserial alternate (Sprinkle, 1973, p. 133, fig. 31b). Mention has already been made of the biserial branched arms of coronoids that start with a single uniserial plate. Thus, although Frest and Strimple (in Frest et al., 2011, pl. 4, figs. 5, 7) illustrated uniserial plates still attached to the ambulacral facets in holocystitid diploporites, it is uncertain that the entire structures were uniserial. In Paulicystis Frest and Strimple, 2011 (in Frest et al., 2011), the ambulacra were recumbent on the theca and appear to have been biserial (Frest et al., 2011, pl. 4, fig. 2).

Cover plates.-Ambulacral cover plates are also poorly known, partly due to preservational deficiencies but also due to less taxonomic significance being placed on them compared with, for example, cover plate arrangements in edrioasteroids (Bell, 1976a, b). It is convenient to discuss cover plates in the three parts of the ambulacral system separately. Cover plates occur over the oral area, along main trunks of arms (as defined here) or ambulacra, and along erect appendages. Clearly, where ambulacral appendages remain unknown (e.g., in the diploporite family Sphaeronitidae), their cover plates must also be unknown. Cover plates in the other two parts of the ambulacral system are better known.

The simplest arrangement of oral cover plates occurs in the diploporite families Sphaeronitidae and Holocystitidae, where the large peristome is covered by six interradial plates, which can be considered as primary oral cover plates (Fig. 5.2, 5.3, 5.6). Paul (1971, p. 7) called these plates palatals, and they were almost certainly immovable in life. In other 'cystoids' in which the mouth is smaller and within a narrow food groove, I think some or all of these palatals can still be recognized. For example, glyptocystitoid rhombiferans have a simple biseries of oral cover plates (e.g., Fig. 3) in which all the palatals (primary oral cover plates of Sumrall, 2008) appear to be recognizable. However, in the eocrinoid Rhopalocystis (see Ubaghs, 1963, pl. 3, figs. 1,2) and in the caryocystitid rhombiferan genera Echinosphaerites (Fig. 6.1-6.3; Bockelie, 1982, p. 493, fig. 2) and Stichocystis Jaekel, 1899 (Bockelie, 1981c, pp. 54, 55, figs. 2a, 3a), only the pair of palatals in the CD interray are easily recognized.

In aristocystitoid diploporites, the broad main food groove is covered by a double biseries of cover plates (Fig. 7.2), and it is not possible to distinguish oral from ambulacral cover plates. This is equally true of the flattened eocrinoid Lingulocystis Thoral, 1935 (Ubaghs, 1968, p. S464, fig. 299.3a). The hemicosmitoid rhombiferan Hemicosmites has biserial cover 
plates over its three ambulacra, of which only the central four appear to be oral cover plates (Fig. 9.1). However, Caryocrinites (Hemicosmitoida) is characterized by an extensive tegmen in which Frest (1975) recognized a central plate surrounded by eight pericentrals and various additional cover plates added as arms were added (Fig. 9.6, 9.7).

Ambulacral cover plates are preserved in a number of 'cystoid' groups. In the eocrinoid Rhopalocystis, there is a simple set of biserial alternate cover plates along the ambulacra, which occasionally have one or two secondary cover plates near the central suture (Ubaghs, 1963, pl. 3, fig. 1). The ambulacral cover plates decrease in size as they approach the brachiole facets. By contrast, in the eocrinoid Ascocystites Barrande, 1887, Ubaghs (1968, p. S483) interpreted the ambulacra as covered by two sets of cover plates. However, he also thought a possible hydropore occurred in the outer cover plates of the $\mathrm{CD}$ interray. It would be extremely unusual for a stone canal to pass through an ambulacrum to open in a cover plate. Sprinkle (1973, p. 118-121) also described Ascocystites, including some of the same specimens seen by Ubaghs, and thought the supposed hydropore was merely some disturbed cover plates. Sprinkle (1973) followed Ubaghs (1968) in thinking the main ambulacra had two sets of paired cover plates, but only the central set continued up the brachioles. Double biserial cover plates are known in the main ambulacra of the diploporite Eumorphocystis (see Parsley, 1982a, p. 285).

Brachiole and pinnule cover plates have been recorded in a variety of genera, and Sprinkle (1973, p. 16, 17, fig. 5) illustrated several different arrangements. The simplest consist of a single biseries of cover plates, one extending from each side of the food groove and meeting in the middle. Even here, two slightly different arrangements are known. In several eocrinoid genera, each cover plate overlaps the next distal one and the two series interlock alternately. Sprinkle (1973, p. 15) called this type 'distally imbricating' cover plates. He recorded them in Kinzercystis Sprinkle, 1973 (fig. 5a), Lepidocystis Foerste, 1938 (p. 65), Lichenoides (p. 110), Eustypocystis Sprinkle, 1973 (p. 113), and Ascocystites (p. 119). Paul (1968, p. 589, fig. 8) illustrated the same arrangement in the glyptocystitoid rhombiferan Macrocystella Callaway, 1877. More commonly, the two series of cover plates meet at a zigzag suture line in the center of the food groove. This arrangement is seen in several species of Gogia Walcott, 1917 (Sprinkle, 1973) and so was probably established by the late lower Cambrian. It is also known in an unnamed rhipidocystid eocrinoid (Sprinkle, 1973, p. 16, fig. 5b), the hemicosmitoid Caryocrinites (Sprinkle, 1973, p. 17, fig. 5f), and the parablastoid Meristoschisma Sprinkle, 1973 (Sprinkle, 1973, p. 17, fig. 5g). The two series of cover plates are slightly unequal in size in the spiral brachioles of Gogia spiralis (Sprinkle, 1973, p. 16, fig. 5d). A simple biserial arrangement occurs in the glyptocystitoid rhombiferans Glyptocystella, Pirocystella, and Strabocystis (Sprinkle, 1982a, pp. 240, 245, and 266, respectively). It even occurs in the uniserial pinnules of the palaeocrinoid Bromidocystis (Sprinkle, 1982b, p. 294) and the paracrinoids Comarocystites, Amygdalocystites, and Malocystites (Parsley and Mintz, 1975, pp. 33, 47, and 89, respectively).

Sprinkle (1973, pp. 16, 17, fig. 5) also illustrated a double biseries of cover plates in the eocrinoid Nolickuckia Sprinkle,
1973 where the two series were side by side on either side of the central suture line. The alternative arrangement for double biseries of cover plates where one series lines the edges of the food groove and the other fills the central region was illustrated for two species of blastoids sensu stricto (s.s.; Sprinkle, 1973, p. 17, fig. 5h, i). Finally, Sprinkle illustrated a complex arrangement of five sets of cover plates in the brachioles of glyptocystitoid rhombiferan Cheirocystis anatiformis (Hall, 1847) (Sprinkle, 1973, p. 16, fig. 5e). Kesling (1962) redescribed this species, but his description of the cover plates is limited. As far as I am aware, no other glyptocystitoid has such complex cover plates in its brachioles, but so few species have been described in sufficient detail that this is not necessarily significant.

Parsley and Mintz (1975, p. 47) raised the possibility that cover plates of main ambulacral grooves in the paracrinoid Amygdalocystites could not open in life, whereas those of the pinnules could. This idea is distinctly possible in other 'cystoid' groups. In particular, the cover plates in the wide main food groove of the ambulacra in aristocystitoid diploporites appear unlikely to have opened in life, whereas it seems most unlikely that cover plates of the brachioles and pinnules of any pelmatozoan echinoderm did not open for feeding.

\section{Summary of ambulacral structure}

The ambulacral structure found in glyptocystitoids with a double biseries of flooring plates and erect biserial brachioles with simple biserial cover plates appears to be least derived in the sense that all the elements are added in series of four columns of plates, but it is much simpler than the arrangement of cover plates in Cambrian echinoderms such as helicoplacoids, helicocystoids, and stromatocystitids. The brachioles have biserial, alternate brachiolar plates and biserial cover plates. The main ambulacrum can be viewed as constructed of the first pair of brachiolar plates modified as flooring plates, and each brachiole arises from a facet shared by two ambulacral flooring plates. Different ratios of cover plates to brachiolars or to flooring plates are analogous to the different numbers of ambulacral and 'interambulacral' plates in sea urchins.

Possibly the first major innovation in ambulacral design was the ability to articulate a biserial brachiole on a single flooring plate, which allowed the development of main ambulacral trunks with a single biseries of flooring or trunk plates. Trachelocrinus apparently represents a variation in which the brachioles still arose from a pair of trunk plates but with a single additional trunk plate that did not bear a brachiole in between each pair that did. Another innovation was the development of ambulacral grooves incised into extraxial plates and from which appendages arose as in the eocrinoid Lichenoides and sphaeronitid diploporite Glyptosphaerites. In Lichenoides, the appendages were brachioles, and more than one arose from the 'radial' plates. However, Sprinkle (1973, p. 110) described the brachioles as changing from biserial alternate over most of their length to biserial opposite near the base and even possibly to a uniserial first brachiolar. The appendages of sphaeronitids remain totally unknown. In both Lichenoides and sphaeronitids there is nothing comparable to a main ambulacral trunk or arm. 
The appearance of uniserial pinnules is another major innovation, but the structures need checking with thin sections to ensure that hidden sutures do not exist. Sprinkle's (1973) description of the structure of the brachioles in Lichenoides provides a plausible mechanism by which uniserial pinnules might arise. Biserial flooring plates from which uniserial pinnules arose are a logical ambulacral structure if the flooring plates are modified first pinnulars. Truly uniserial main ambulacral trunks occur in North American paracrinoids whose pinnules only arise from one side of the ambulacrum (usually the left side). This structure is still compatible with the idea that flooring plates are modified first pinnulars. So far as is known, all pinnules had biserial cover plates, but very few have been described in detail. It is interesting to note that Sprinkle and Parsley (1982, p. 228) described the unusual paracrinoid Bistomiacystis as having the most distal ambulacral plate in each ambulacrum being larger than usual and possibly being a terminal ambulacral plate analogous to those in starfish. Bistomiacystis has two oral openings; four ambulacra are curved counterclockwise and have facets on their right sides; and the associated appendages appear to have been biserial. It seems to have doubled everything associated with its axial skeleton.

Uniserial plates that form part of the thecal wall and may be extraxial in origin occur in gomphocystitids. The ambulacra spiral clockwise, and the appendage facets are all on the lefthand side. Unfortunately, the appendages are unknown, so it is not possible to argue that the ambulacral plates are modified first brachiolars or pinnulars. The unique triserial plating to the erect ambulacra of the diploporite Eumorphocystis remains puzzling. The biserial arm plates with facets for the pinnules make sense as modified first pinnulars, but the third, aboral, uniserial series of plates is apparently without homology within the Echinodermata.

Finally, ambulacral cover plates show no evidence of musculature by which they could have been opened. Their structure, shape, and orientation when closed resemble those of anal and gonal pyramids, except that they cover narrow elongate grooves rather than more-or-less circular holes. Both anal and gonal pyramid plates lack any evidence of musculature to open them. In life, they acted as one-way valves allowing egress from the theca (Paul, 1967a, p. 305-306). In some rhombiferans (e.g., Echinosphaerites, see Barrande, 1887, pl. 23, fig. 7), the anal plates have large lateral ligament or muscle pits on the interior surface, which closed the anal pyramid. Voiding of fecal pellets was by peristalsis. The similarity between the cover plates of food grooves and the pyramids over thecal orifices suggests that the only way to open cover plates was by pressure from the inside, and inflation of tube feet is the most obvious way to achieve this.

Details of cover plates need further investigation. For example, were cover plates of main food grooves permanently closed? Once food had been gathered in the brachioles, it needs to be transferred to the mouth without loss. Immovable cover plates would aid this process.

\section{Discussion}

Stephenson (1979) argued that a trimerous stage in echinoderm evolution was unnecessary to the origin of pentamery. At the time, helicoplacoids were thought to have a single ambulacrum that branched once (Durham and Caster, 1963; Durham, 1967). Now we know that triradiate echinoderms actually existed. Smith and Zamora (2013) have added further Cambrian spiral echinoderms in Helicocystis, which is thought to be the latest common ancestor of all pentameral echinoderms. Smith and Zamora (2013, p. 4) stated that the helicoplacoids spiraled counterclockwise, whereas Helicocystis spiraled clockwise. This is an unexpected difference and weakens the argument that Helicocystis is directly intermediate between triradiate helicoplacoids and pentameral echinoderms. However, if one orients both with the mouth toward the observer and with ambulacrum A toward the top of the diagram (the standard orientation for pentameral pelmatozoans), all the ambulacra in both forms spiral clockwise (Fig. 19). The ambulacra spiral to the right in relation to their direction of growth.

Numerous echinoderms have spiral ambulacra, and in those with erect appendages these always occur on the outside of the curve. Most have ambulacra that spiral clockwise and have facets on the left side. I presume this arrangement occurs for reasons of space; there is more room for brachioles or pinnules on the outside of curved ambulacra than on the inside. This would be particularly true of small individuals or juveniles. Further possible evidence for clockwise spirals in 'cystoids' includes the addition of ambulacral facets clockwise in multifaceted sphaeronitids such as Archegocystis, Haplosphaeronis, and Tetreucystis (Paul, 1973; Bockelie, 1978). Bockelie (1982) also concluded that the addition of ambulacra in the Caryocystitoida was clockwise, first from the B and then from the D ambulacrum. It is interesting to note that Rozhnov (1994, p. 174) argued that the addition of ambulacral plates in the eocrinoids Cryptocrinites and Rhipidocystis Jaekel, 1900 occurred in a clockwise direction and in the order ambulacrum $\mathrm{D}$, then $\mathrm{B}$, then C or E, and last A. Bockelie (1981b, fig. 10a, b) also illustrated two examples of Cryptocrinites from Norway, with only one facet in ambulacrum A, but two in all others. In one, the smallest and most recently added was in ambulacrum E, and in the other in ambulacrum C. This matches the order suggested by Rozhnov (1994). If Rozhnov's order of addition of ambulacral plates is widespread among 'cystoid' groups, it might explain why all 'cystoids' with four ambulacra lack ambulacrum A. It was presumably aborted before any ambulacral plates were developed. It might also be relevant to the 'BD different' pattern of primary brachioles in glyptocystitoids with five ambulacra.

Zamora and Rahman (2015) have recently reviewed the Cambrian echinoderms, including their oral plating. There is a surprising diversity of oral plating making detection of a plesiomorphic state more difficult. Regrettably, the oral plating in helicoplacoids remains unknown despite recent attempts to elucidate it. Interestingly, the lower Cambrian imbricate 'eocrinoid' Lepidocystis has a circum-oral circlet (Sprinkle, 1973, pl. 3, fig. 3; reproduced in Kammer et al., 2013, p. 8, fig. 4m, and Zamora and Rahman, 2015, p. 1115, fig. 6e). By contrast, the middle Cambrian edrioasteroid Kailidicus Zhao et al., 2010 apparently has a typical peri-oral circlet (see Kammer et al. 2013 , p. 8 , fig. 4a, b), although in the latter case the ambulacra appear to form the mouth frame. It is puzzling that only a single plate of the biserial ambulacra of many 'cystoids' was modified as a mouth frame plate The clockwise spiral ambulacra of Helicocystis 

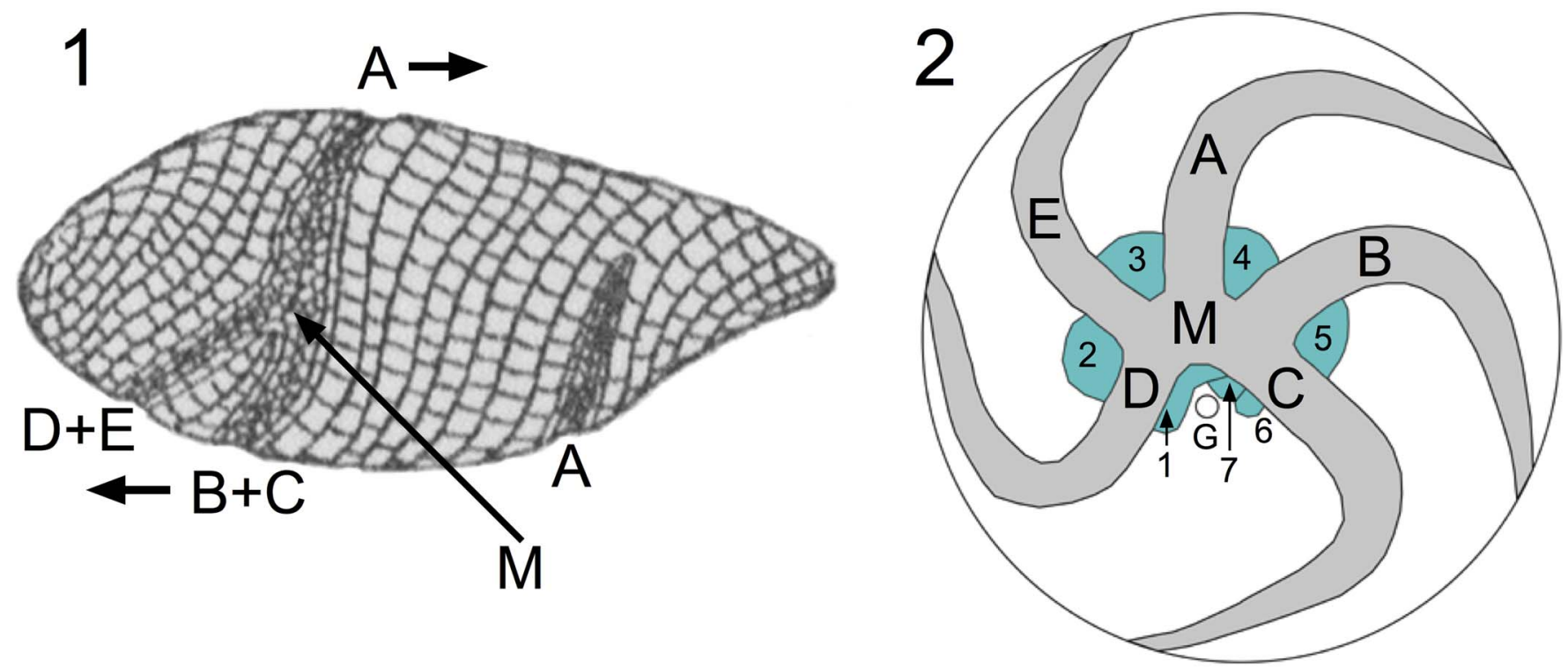

Figure 19. Oral views of (1) a helicoplacoid and (2) a helicocystoid in the same orientation with abulacrum A at the top. In both, the ambulacra are twisted in a clockwise direction (arrows in 1) as viewed from the mouth (M). A-E = ambulacra; $\mathrm{G}=$ position of gonopore; $1-7=$ peri-oral plates in helicocystoid. (1) Modified from Paul and Smith (1984, fig. 19).

may explain this and why almost all 'cystoids' have the first branch of the ambulacrum (to brachioles or pinnules) on the left. In spiral ambulacra, the outer plates are enlarged and brachioles are usually confined to the outer side, which is the left side in clockwise spirals.

Thus, the basic pattern of seven peri-oral plates, as in Helicocystis (Fig. 13), may arise from clockwise spiral ambulacra favoring the first ambulacral plate on the left of each ambulacrum over the right one and so developing five large interradial peri-orals. The sixth peri-oral in the $\mathrm{CD}$ interradius usually bears half the hydropore, and the seventh is often associated with the gonopore. Both apertures frequently open across plate sutures, which allows for enlargement of the orifice without resorption of thecal plates. This pattern of oral plates may be plesiomorphic for 'cystoids,' so departures from it are derived.

\section{Conclusions}

The EAT provides a basis for investigating growth and homology of ambulacral and oral plating in 'cystoids,' although it is possible that exceptions to the terminal addition of plates occurred in Paleozoic echinoids with multiple columns of ambulacral plates. Certainly, radial water vessels branched throughout their length in Neobothriocidaris.

Ambulacral homologies are now understood with the hydropore and/or single gonopore in the $\mathrm{CD}$ interray of Carpenter. Where a 2-1-2 ambulacral pattern exists, the CD interrray is always opposite the single unbranched ambulacrum (A). Where fewer than five ambulacra occur, it is usually possible to suggest which ambulacra failed to develop. Oral plate homologies are next best understood, though the origin of some patterns remains obscure. Homologies of ambulacral structure are still challenging, not least because many remain unknown.

All ambulacral branching patterns can be explained assuming developmental genes involved three instructions: 'branch,' 'grow,' and 'stop growing.' Numbers of ambulacra can be reduced if the first 'branch' instruction is suppressed. From observed variation in patterns of ambulacral numbers, this failure to branch acted independently in all five ambulacra and occurred either before or after secretion of associated oral plates in different groups of 'cystoids.'

Two fundamental patterns of six orals forming the mouth frame, often with a seventh associated with the hydropore and/ or single gonopore, occur in early pentameral echinoderms. In circum-oral circlets, five orals are radial, and the sixth interradial is in the $\mathrm{CD}$ interambulacrum. In peri-oral circlets, all orals are inter-radial, with two in the CD interambulacrum. Patterns where two primary ambulacral plates contribute to the mouth frame, as in echinoids and asteroids, occur rarely and appear to be derived. Reduction to five peri-orals forming the mouth frame apparently occurred in at least two ways. Caryocystitoid rhombiferans lack PO3, the peri-oral associated with the undeveloped ambulacrum A, whereas Eumorphocystis either lacks PO6 or it has fused with PO1. Alternatively, all seven peri-orals are present in glyptocystitoid rhombiferans where some genera have 1, 2, 3, 4, or all 5 ambulacra. Failure to develop one or more ambulacra did not result in loss of the associated peri-oral plates.

Knowledge of the detailed structure of ambulacra and especially erect appendages (brachioles or pinnules) is lacking in many 'cystoid' groups. Nevertheless, all ambulacral plates (trunk or flooring plates, brachiolars or pinnulars, cover plates) bear the same topological relationship to inferred branches of the water vascular system (radial water vessels, lateral branches, tube feet). Main ambulacral flooring plates may form part of the thecal wall or be erect or recumbent on extraxial thecal plates. In glyptocystitoid and hemicosmitoid Rhombifera, the first pair of brachiolar plates on each side of an ambulacrum are modified to form the double biseries of flooring or trunk plates. Each brachiole arises from a facet shared by two flooring or trunk 
plates. In paracrinoids, both the flooring plates of the main ambulacra and the erect pinnules are uniserial. The flooring plates are again modified first pinnulars but are uniserial simply because pinnules only arise from one side of the ambulacra. Pinnular facets are confined to single flooring plates. More derived ambulacral structures occur where biserial brachioles arise from facets on single flooring plates in a simple biserial arrangement. A variety of ambulacral structures occurs in 'cystoids.' Lack of detailed knowledge of such structures in many Cambrian 'cystoids' makes it difficult to decide which are likely to be plesiomorphic. Details of any transitions between biserial and uniserial structures are uncertain.

Many ambulacral structures conform to the ideal design for an efficient filter and match similar structures in modern crinoids. For this and other reasons, 'cystoids' probably possessed extensions of the water vascular system in their ambulacra.

Cover plates of main ambulacral grooves may not have opened in life, whereas those of brachioles and pinnules must have done so. There is no evidence for any musculature to open cover plates in either main ambulacral grooves or brachioles and pinnules. The simplest way to open cover plates is by erecting underlying tube feet-another reason for believing extensions of the water vascular system occurred in the 'cystoid' ambulacra. The complete absence of cover plates in the food grooves of Lichenoides and sphaeronitid diploporites is particularly puzzling.

\section{Acknowledgments}

I am grateful to A.B. Smith for providing key references and being an inspirational colleague for many years now. S. Zamora, Geological Survey, Spain, kindly provided the original of Figure 13. S. Zamora and I.A. Rahman also furnished some key references. A. Smith and B. Lefebvre produced thorough and thought-provoking reviews of the original manuscript. I am also indebted to Y. Makhlouf and B. Lefebvre, University Claud Bernard, Lyon, for latex moulds of some critical diploporites originally described by J. Chauvel and J. Barrande, respectively.

\section{Accessibility of supplementary data}

Data available from the Dryad Digital Repositary: http://doi.org/ 10.5061/ dryad.n2d7d.

\section{References}

Angelin, N.P., 1878, Iconographia Crinoideorum in Stratis Sueciae Siluricis Fossilium: Holmiae, $32 \mathrm{p}$.

Barrande, J., 1846, Note Préliminaire Sur le Systême Silurien et les Trilobites de Bohême: Leipzig, 97 p.

Barrande, J., 1887, Systême Silurien du Centre de la Bohême. Première Partie, Recherches Paléontologiques, v. 7. Classe des Echinodermes, Ordre des Cystidées: Prague, W. Waagen, 233 p.

Bassler, R.S., 1935, The classification of the Edrioasteroidea: Smithsonian Miscellaneous Collections, v. 93, part 8, p. 1-11.

Bassler, R.S., 1950, New genera of American Middle Ordovician 'Cystoidea': Journal of the Washington Academy of Sciences, v. 40, p. 273-277.

Bather, F.A., 1900, The Echinoderma, in Lankester, E.R., ed., A Treatise on Zoology, Part 3: London, A \& C Black, 344 p.

Bather, F.A., 1918, Notes on Yunnan cystoids. 2. The species of Sinocystis: Geological Magazine, v. 55, p. 532-540.

Beaver, H.H., 1968, Morphology [of blastoids], in Moore, R.C. ed., Treatise on Invertebrate Paleontology, Part S, Echinodermata 1: Lawrence, Kansas, Geological Society of America and University of Kansas, p. S300-S350.
Bell, B.M., 1976a, Phylogenetic implications of ontogenetic development in the class Edrioasteroidea (Echinodermata): Journal of Paleontology, v. 50, p. 1001-1019.

Bell, B.M., 1976b, A study of North American Edrioasteroidea: New York State Museum, Memoir v. 21, p. 1-447.

Billings, E., 1854, On some new genera and species of Cystidea from the Trenton Limestone: Canadian Journal, v. 2, p. 215-219, 250-253, 268-274.

Billings, E., 1858, Figures and descriptions of Canadian organic remains: Decade 3: Ottawa, Canada, Geological Survey of Canada, 102 p.

Bockelie, J.F., 1978, Variability of ambulacral structures in some diploporite cystoids: Thalassia Jugoslavica, v. 12 (for 1976), p. 31-39.

Bockelie, J.F., 1979a, Celticystis n. gen., a gomphocystitid cystoid from the Silurian of Sweden: Geologiska Föreningens i Stockholm Förhandlingar, v. 101 , p. $157-166$.

Bockelie, J.F., 1979b, Taxonomy, functional morphology and palaeoecology of the Ordovician cystoid family Hemicosmitidae: Palaeontology, v. 22, p. 363-406.

Bockelie, J.F., 1981a, Functional morphology and evolution of the cystoid Echinosphaerites: Lethaia, v. 14, p. 189-202.

Bockelie, J.F., 1981b, The Middle Ordovician of the Oslo Region, Norway, 30. The eocrinoid genera Cryptocrinites, Rhipidocystis and Bockia: Norsk Geologisk Tidsskrift, v. 61, p. 123-147.

Bockelie, J.F., 1981c, A re-evaluation of the Ordovician cystoid Stichocystis Jaekel and the taxonomic implications: Geologiska Föreningens i Stockholm Förhandlingar, v. 103, p. 51-59.

Bockelie, J.F., 1982, Symmetry and ambulacral pattern of the rhombiferan superfamily Caryocystitida and the relationship to other Blastozoa: Geologiska Föreningens i Stockholm Förhandlingar, v. 103, p. 491-498.

Bockelie, J.F., 1984, The Diploporita of the Oslo region, Norway: Palaeontology, v. 27 , p. $1-68$

Branson, E.B., and Peck, R.E., 1940, A new cystoid from the Ordovician of Oklahoma: Journal of Paleontology, v. 14, p. 89-92.

Brett, C.E., Frest, T.J., Sprinkle, J., and Clement, C.R., 1983, Coronoidea: A new class of blastozoan echinoderms based on taxonomic reevaluation of Stephanocrinus: Journal of Paleontology, v. 57, p. 627-651.

Broadhead, T.W., and Strimple, H.L., 1978, Systematics and distribution of the Callocystitidae (Echinodermata, Rhombifera): Journal of Paleontology, v. 52 , p. $164-177$.

Callaway, C., 1877, On a new area of upper Cambrian rocks in south Shropshire, with a description of a new fauna: Quarterly Journal of the Geological Society, London, v. 33, p. 652-672.

Carpenter, P.H., 1884, Report upon the Crinoidea collected during the voyage of HMS Challenger during the years 1873-76, part 1. General morphology with descriptions of the stalked crinoids: Reports of the Scientific Results of the Voyage of HMS Challenger: Zoology, v. 11, p. 1-442.

Carpenter, P.H., 1891, On certain points of the morphology of the Cystidea: Journal of the Linnean Society (Zoology), v. 34, p. 1-52.

Chauvel, J., 1941, Recherches sur les Cystoïdes et les Carpoïdes Armoricains: Société Géologique et Minéralogigue de Bretagne, Mémoires, v. 5, p. 1-286.

Chauvel, J., 1966, Échinodermes de l'Ordovicien du Maroc: Cahiers de Paléontologie, (1966), p. 1-120.

Chauvel, J., 1977, Calix sedgwicki Rouault (Échinoderme Cystoïde, Ordovicien du Massif armoricain) et l'appareil ambulacraire des Diploporites: Société Géologique de France, Compte Rendus Sommaires des Séances, 1977, p. 314-317.

Chauvel, J., and le Menn, J., 1979, Sur quelques échinodermes (Cystoïdes et crinoïdes) de l'Ashgill d'Aragon (Espagne): Géobios, v. 12, p. 549-587.

Chen, Z.T., and Yao, J.H., 1993, Palaeozoic Echinoderm Fossils of Western Yunnan, China: Beijing, Geological Publishing House, 102 p. (in Chinese).

Conrad, T.A., 1842, Observations of the Silurian and Devonian systems of the United States, with descriptions of new organic remains: Journal of the Academy of Natural Sciences in Philadelphia, v. 8, p. 183-190.

David, B., and Mooi, R., 1998, Major events in the evolution of echinoderms viewed in the light of embryology, in Mooi, R., and Telford, M., eds., Echinoderms, San Francisco: Rotterdam, Balkema, p. 21-28.

Derstler, K.L., 1981, Morphological diversity of early Cambrian echinoderms, in Taylor, M.E., ed., Short Papers for the Second International Symposium on the Cambrian System: United States Open File Report, 81-743, p. 71-75.

Donovan, S.K., and Paul, C.R.C., 1985, Coronate echinoderms from the lower Palaeozoic of Britain: Palaeontology, v. 28, p. 527-543.

Durham, J.W., 1967, Notes on the Helicoplacoidea and early echinoderms: Journal of Paleontology, v. 41, p. 97-102.

Durham, J.W., and Caster, K.E., 1963, Helicoplacoidea: A new class of echinoderms: Science, v. 140, p. 820-822.

Eichwald, E. von, 1840, Ueber das silurische Schichtensystem in Esthland: Zeitschrift für Natur- und Heilkunde der medizinischen Akademie zu St Petersburg, v. 1, p. 1-222 (also published in French). 
Fay, R.O., 1962, The ventral structures of Stephanocrinus angulatus Conrad: Journal of Paleontology, v. 36, p. 206-210.

Foerste, A.F., 1938, Echinodermata, in Resser, C.E., and Howell, B.F., eds., Lower Cambrian Olenellus Zone of the Appalachians: Geological Society of America, Bulletin, v. 49, p. 212-213.

Frest, T.J., 1975, Caryocrinitidae (Echinodermata: Rhombifera) of the Laurel Limestone of Southeastern Indiana: Fieldiana: Geology, v. 30, p. 81-106.

Frest, T.J., and Strimple, H.L., 1976, Evolutionary and paleoecological significance of abnormal Platycystites cristatus Bassler (Echinodermata: Paracrinoidea): Washington Academy of Sciences, Journal, v. 66 , p. 221-228.

Frest, T.J., Strimple, H.L., and McGinnis, M.R., 1976, A new species of Platycystites (Echinodermata: Paracrinoidea) from the Middle Ordovician of Oklahoma: Washington Academy of Sciences, Journal, v. 66, p. 211-221.

Frest, T.J., Strimple, H.L., and Paul, C.R.C., 2011, The North American Holocystites Fauna (Echinodermata: Blastozoa: Diploporita): Paleobiology and systematics: Bulletins of American Paleontology, 380, $141 \mathrm{p}$.

Gale, A.S., 2011, The phylogeny of post-Palaeozoic Asteroidea (Neoasteroidea, Echinodermata): Special Papers in Palaeontology, v. 85, p. 1-112.

Hall, J., 1847, Palaeontology of New York, Volume 1, Containing Descriptions of the Organic Remains of the Lower Division of the New-York System (Organic Remains of the Trenton Limestone). Natural History of New York, Part 6: Albany, New York, D. Appleton and Wiley and Putnam, p. 60-249.

Hall, J., 1852, Palaeontology of New York, Volume 2, Containing Descriptions of the Organic Remains of the Lower Middle Division of the New-York System. Natural History of New York, Part 6: Albany, New York, D. Appleton and Wiley and Putnam, vii+362 p.

Hall, J., 1859, Palaeontology of New York, Volume 3, Descriptions of the Organic Remains of the Lower Helderberg Group and the Oriskany Sandstone. Natural History of New York, Part 6: Albany, New York, D. Appleton and Wiley and Putnam, $532 \mathrm{p}$.

Hall, J., 1861, Descriptions of new species of fossils, in Report of the superintendent of the Geological Survey [of Wisconsin], Madison, Wisconsin p. $9-52$.

Hall, J., 1864, Account of some new and little known species of fossils from rocks of the age of the Niagara Group: Advanced sheets New York State Cabinet of Natural History, Report, v. 18, p. 1-16. (The full paper eventually appeared in 1868 , in the 20th report, pp. 305-401.)

Hyman, L.H., 1955, The Invertebrates: Echinodermata, The Coelomate Bilateria: New York, McGraw-Hill, 763 p.

Jackson, R.T., 1912, Phylogeny of the Echini, with a revision of the Palaeozoic species: Boston Society of Natural History, Memoir 7, $490 \mathrm{p}$.

Jaekel, O., 1895, Über die Organisation der Cystoideen: Deutsche Zoologische Gesellschaft Verhandlungen, v. 5, p. 109-121.

Jaekel, O., 1899, Stammesgeschichte der Pelmatozoen. 1. Thecoidea und Cystoidea: Berlin, Julius Springer, $442 \mathrm{p}$.

Jaekel, O., 1900, Ueber Carpoideen, eine neue Classe von Pelmatozoen: Deutsche Zoologische Gesellschaft, Zeitschrift, v. 52, p. 661-677.

Kammer, T.W., Sumrall, C.D., Zamora, S., Ausich, W.I., and Deline, B., 2013, Oral region homologies in Paleozoic crinoids and other plesiomorphic pentaradial echinoderms: PLoS One, 8, no. 11: e77989, doi: 10.1371/ journal.pone.0077989.

Kesling, R.V., 1961, Notes on Jaekelocystis hartleyi and Pseudocrinites gordoni, two rhombiferan cystoids described by Charles Schuchert in 1903 Museum of Paleontology, University of Michigan, Contributions, v. 16, p. 245-273.

Kesling, R.V., 1962, Morphology and taxonomy of the cystoid Cheirocrinus anatiformis (Hall): Museum of Paleontology, University of Michigan, Contributions, v. 18 , p. 1-21.

Kesling, R.V., 1968a, Cystoids, in Moore, R.C., ed., Treatise on Invertebrate Paleontology, Part S, Echinodermata 1: Lawrence, Kansas, Geological Society of America and University of Kansas, p. S85-S267.

Kesling, R.V., 1968b, Paracrinoids, in Moore, R.C., ed., Treatise on Invertebrate Paleontology, Part S, Echinodermata 1: Lawrence, Kansas, Geological Society of America and University of Kansas, p. S268-S288.

Kier, P.M., 1965, Evolutionary trends in Paleozoic echinoids: Journal of Paleontology, v. 39, p. 436-465.

Lanc, F.A., McDermott, P.D., and Paul, C.R.C., 2015, The identity of the British Ordovician cystoid 'Hemicosmites rugatus Forbes': Geological Journal, v. 50, p. 1-16. doi: $10.1002 /$ gj.2522.

Lefebvre, B., Nardin, E., and Fatka, O., 2015, Body wall homologies in basal blastozoans, in Zamora, S., and Rábano, I., eds., Progress in Echinoderm Palaeobiology: Madrid, Instituto Geológico y Minero de España, p. 87-93.

Lovén, S., 1874, Études sur les échinidées: Bihang Konglige Svenska Vetenskaps Akademiens, Handlingar, v. 11, no. 7, p. 3-92.

Makhlouf, Y., Lefebvre, B., Nardin, E., Nedjari, A., and Paul, C.R.C., in press, Lepidocalix pulcher Termier and Termier, 1950 from the Middle Ordovician of northern Algeria: Taxonomic revision and palaeoecological implications: Acta Palaeontologica Polonica.
Männil, R., 1962, The taxonomy and morphology of Bothriocidaris: ENSV Teaduste Akadeemia Geoloogia Instituudi Uurimused, v. 9, p. $143-190$.

Meek, F.B., 1871, On some new Silurian crinoids and shells: American Journal of Science, Series 3, v. 3, p. 257-262.

Miller, S.A., 1878, Descriptions of eight new species of Holocystites from the Niagara group: Cincinnati Society of Natural History, Journal, v. 1, p. $129-136$.

Miller, S.A., 1879, Descriptions of twelve new fossil species, and remarks upon others: Cincinnati Society of Natural History, Journal, v. 2, p. $104-118$.

Miller, S.A., 1889, North American Geology and Palaeontology: Cincinnati, Ohio, Western Methodist Book Concern, 664 pp.

Miller, S.A., 1891, Advanced sheets from the seventeenth report of the geological survey of Indiana, Palaeontology: Indianapolis, p. 1-94.

Mooi, R., and David, B., 2008, Radial symmetry, the anterior/posterior axis, and echinoderm Hox genes: Annual Review of Ecology, Evolution, and Systematics, v. 39, p. 43-62.

Mooi, R., David, B., and Marchand, D., 1994, Echinoderm skeletal homologies: Classical morphology meets modern phylogenetics, in David, B., Guille, A., Féral, J., and Roux, M., eds., Echinoderms Through Time: Rotterdam, A.A. Balkema, p. 87-95.

Mooi, R., David, B., and Wray, G.A., 2005, Arrays in rays: Terminal addition in echinoderms and its correlation with gene expression: Evolution and Development, v. 7, p. 542-555.

Müller, J.H.J., 1854, Über den Bau der Echinodermen: königlichen preussischen Akademie der Wissenschaften, Abhandlungen (1853), p. 123-219.

Nichols, D., 1960, The histology and activities of the tube-feet of Antedon bifida: Quarterly Journal of Microscopical Science, v. 101, p. 105-117.

Parsley, R.L., 1978, Thecal morphology of the Ordovician paracrinoid Comar ocystites (Echinodermata): Journal of Paleontology, v. 52, p. 472-479.

Parsley, R.L., 1982a, Eumorphocystis, in Sprinkle, J., ed., Echinoderm faunas from the Bromide Formation (Middle Ordovician) of Oklahoma: University of Kansas Paleontological Contributions, Monograph, 1, p. 280-288.

Parsley, R.L., 1982b, Paracrinoids, in Sprinkle, J., ed., Echinoderm faunas from the Bromide Formation (Middle Ordovician) of Oklahoma: University of Kansas Paleontological Contributions, Monograph, 1. p. 212-223.

Parsley, R.L., 1990, Aristocystites, a recumbent diploporid (Echinodermata) from the Middle and Late Ordovician of Bohemia, ČSSR: Journal of Paleontology, v. 64, p. 278-293.

Parsley, R.L., and Mintz, L.W., 1975, North American Paracrinoidea: (Ordovician: Paracrinozoa, new, Echinodermata): Bulletins of American Paleontology, v. 288, 115 p.

Patterson, C., 1982, Morphological characters and homology, in Joysey, K.A and Friday A.E., eds., Problems of phylogenetic reconstruction: Systematics Association Special Volume, 21, p. 21-74.

Patterson, C., 1988, Homology in classical and molecular biology: Molecular Biology and Evolution, v. 5, p. 603-625.

Paul, C.R.C., 1967a, The British Silurian cystoids: British Museum (Natural History) Bulletin: Geology, v. 13, p. 299-355.

Paul, C.R.C., 1967b, The functional morphology and mode of life of the cystoid Pleurocystites E. Billings, 1854: Zoological Society of London, Symposia, v. 20, p. $105-121$.

Paul, C.R.C., 1967c, New Ordovician Bothriocidaridae from Girvan and a reinterpretation of Bothriocidaris: Palaeontology, v. 11, p. 697-730.

Paul, C.R.C., 1968, Macrocystella Callaway, the earliest glyptocystitid cystoid: Palaeontology, v. 11, p. 580-600.

Paul, C.R.C., 1969, Thomacystis, a unique new hemicosmitid cystoid from Wales: Geological Magazine, v. 106, p. 190-196.

Paul, C.R.C., 1971, Revision of the Holocystites fauna (Diploporita) of North America: Fieldiana Geology, v. 24, p. 1-166.

Paul, C.R.C., 1972, Cheirocystella antiqua gen. et sp. nov. from the Lower Ordovician of western Utah, and its bearing on the evolution of the Cheirocrinidae (Rhombifera, Glyptocystitida): Geology Studies of Brigham Young University, v. 19, p. 15-63.

Paul, C.R.C., 1973, British Ordovician cystoids, Part 1: Palaeontographical Society, Monograph, v. 127, p. 1-64.

Paul, C.R.C., 1984, British Ordovician cystoids, Part 2: Palaeontographical Society, Monograph, v. 136, p. 65-152.

Paul, C.R.C., 1988, The phylogeny of the cystoids, in Paul, C.R.C., and Smith, A.B., eds., Echinoderm Phylogeny and Evolutionary Biology: Oxford, Clarendon Press, p. 199-213.

Paul, C.R.C., 1997, British Ordovician cystoids, Part 3: Palaeontographical Society, Monograph, v. 151, p. 153-213.

Paul, C.R.C., 2015, Callocystites fresti sp. nov., and the significance of ambulacral branching in the Callocystitidae (Echinodermata, Glyptocystitoida): Geological Journal, v. 50, p. 189-209, doi: 10.1002/gj.2545.

Paul, C.R.C., and Donovan, S.K., 2011, A review of the British Silurian cystoids: Geological Journal, v. 46, p. 434-450. 
Paul, C.R.C., and Fone, W., 1997, Third addendum to part 1, in British Ordovician Cystoids, part 3: Palaeontographical Society, Monograph, v. 151, p. $155-159$.

Paul, C.R.C., and Smith, A.B., 1984, The early radiation and phylogeny of echinoderms: Biological Reviews, v. 59, p. 443-481.

Pearce, J.C., 1843, On an entirely new form of encrinite from the Dudley Limestone: Proceedings of the Geological Society, London, v. 4, p. 160.

Prokop, R., 1964, Sphaeronitoidea Neumayr of the lower Paleozoic of Bohemia: Sborník Geologických věd, Paleontologie, v. 3, p. 7-37.

Reed, F.R.C., 1917, Ordovician and Silurian fossils from Yun-nan: Geological Survey of India, Memoirs, Palaeontographica Indica, new series, v. 6, p. 1-69.

Regnéll, G., 1945, Non-crinoid Pelmatozoa from the Paleozoic of Sweden: Lunds Geologisk-Mineralogiska Institutionen, Meddelanden, v. 108, p. $1-255$.

Rouault, M., 1851, Mémoire sur le terrain paléozoïque des environs de Rennes: Bulletin de la Société géologique de France, v. 2, p. 358-399.

Rozhnov, S.V., 1987, New data on eocrinoids with flattened theca: Akademii Nauk SSSR, Doklady, Earth Science Section, v. 295, p. 965-968 (in Russian).

Rozhnov, S.V., 1994, Comparative morphology of Rhipidocystis Jaekel, 1900 and Cryptocrinites von Buch, 1840 (Eocrinoidea; Ordovician), in David, B., Guille, A., Féral, J., and Roux, M., eds., Echinoderms Through Time: Rotterdam, Balkema, p. 173-178.

Rozhnov, S.V., 2012, Reinterpretation of Baltic Ordovician Heckerites multistellatus Rozhnov, 1987 as a possible paracrinoid based on new material: Zoosymposia, v. 7, p. 307-316.

Rozhnov, S.V., 2015, On the paracrinoid-like echinoderms Achradocystites Volborth, 1870 and Heckerites Rozhnov, 1987 from the Ordovician of Baltica, in Zamora, S. and Rábano, I., eds., Progress in Echinoderm Palaeobiology: Madrid, Instituto Geológico y Minero de España, p. $147-150$.

Ruedemann, R., 1933, Camptostroma, a lower Cambrian floating hydrozoan: United States National Museum, Proceedings, v. 82, no. 13, p. 1-8.

Say, T., 1825, On two genera and several species of Crinoidea: Academy of Natural Sciences, Philadelphia, Journal, v. 4, p. 289-296.

Schuchert, C., 1903, On new Siluric Cystoidea and a new Camarocrinus: American Geologist, v. 32, p. 230-240.

Schuchert, C., 1904, On Siluric and Devonic Cystidea and Camarocrinus: Smithsonian Miscellaneous Collections, v. 47, p. 201-272.

Sheffield, S.L., and Sumrall, C.D., 2015, A new interpretation of oral plating patterns of the Holocystites fauna (Diploporita, Echinodermata), in Zamora, S., and Rábano, I., eds., Progress in Echinoderm Palaeobiology: Madrid, Instituto Geológico y Minero de España, p. 159-162.

Simms, M.J., 1999, Systematics, phylogeny and evolutionary history, in Hess, H., Ausich, W.I., Brett, C.E., and Simms, M.J., eds., Fossil Crinoids: New York, Cambridge University Press, p. 31-40.

Sinclair, G.W., 1945, Some Ordovician echinoderms from Oklahoma: American Midland Naturalist, v. 34, p. 707-716.

Smith, A.B., and Zamora, S., 2013, Cambrian spiral-plated echinoderms from Gondwana reveal the earliest pentaradial body plan: Royal Society London, Proceedings, v. B280, doi: 10.1098/rspb.2013.1197.

Solovjev, A.N., 2009, Morphology, systematic position, and distribution of bothriocidarid echinoids: Paleontological Journal, v. 43, p. 1415-1424.

Sprinkle, J., 1973, Morphology and evolution of blastozoan echinoderms: Museum of Comparative Zoology, Harvard University, Special Publication, 284 p.

Sprinkle, J., 1975, The "arms" of Caryocrinites, a rhombiferan cystoid convergent on crinoids: Journal of Paleontology, v. 49, p. 1062-1073.

Sprinkle, J., 1982a, Cylindrical and globular rhombiferans, in Sprinkle, J., ed., Echinoderm faunas from the Bromide Formation (Middle Ordovician) of Oklahoma: University of Kansas Paleontological Contributions, Monograph, 1, p. 231-273.

Sprinkle, J., 1982b, Palaeocystitids, in Sprinkle, J., ed., Echinoderm faunas from the Bromide Formation (Middle Ordovician) of Oklahoma: University of Kansas Paleontological Contributions, Monograph, 1, p. 289-296.

Sprinkle, J., and Parsley, R.L., 1982, "Golf-ball" paracrinoid, in Sprinkle, J., ed., Echinoderm faunas from the Bromide Formation (Middle Ordovician) of Oklahoma: University of Kansas Paleontological Contributions, Monograph, 1, p. 224-230.

Stephenson, D.G., 1979, The trimerous stage in echinoderm evolution: An unnecessary hypothesis: Journal of Paleontology, v. 53, p. 44-48.

Sumrall, C.D., 1997, The role of fossils in the phylogenetic reconstruction of Echinodermata, in Waters, J.A., and Maples, C.M., eds., Geobiology of echinoderms: Paleontological Society, Papers, v. 3, p. 267-288.

Sumrall, C.D., 2008, The origin of Lovén's Law in glyptocystitoid rhombiferans and its bearing on the plate homology and the heterochronic evolution of the hemicosmitoid peristomial border, in Ausich, W.I., and Webster, G.D., eds.,
Echinoderm Paleobiology: Bloomington, University of Indiana Press, p. $228-241$.

Sumrall, C.D., 2010, A model for elemental homology for the peristome and ambulacra in blastozoan echinoderms, in Harris, L.G., Böttger, S.A., Walker, C.W., and Lesser, M.P., eds., Echinoderms: Durham: London, CRC Press, p. 269-276.

Sumrall, C.D., 2015, Understanding the oral area of derived stemmed echinoderms, in Zamora, S., and Rábano, I., eds., Progress in Echinoderm Palaeobiology: Madrid, Instituto Geológico y Minero de España, p. 169-173.

Sumrall, C.D., and Deline, B., 2009, A new species of the dual-mouthed paracrinoid Bistomiacystis and a redescription of the edrioasteroid Edrioaster priscus from the Upper Ordovician Curdsville Member of the Lexington Limestone: Journal of Paleontology, v. 83, p. 135-139.

Sumrall, C.D., and Waters, J.A., 2012, Universal elemental homology in glyptocystitoids, hemicosmitoids, coronoids and blastoids: Steps toward echinoderm phylogenetic reconstruction in derived Blastozoa: Journal of Paleontology, v. 86, p. 956-972.

Sumrall, C.D., and Wray, G.A., 2007, Ontogeny in the fossil record: Diversification of body plans and the evolution of "aberrant" symmetry in Paleozoic echinoderms: Paleobiology, v. 33. P. 149-163.

Sumrall, C.D., Sprinkle, J., and Guensburg, T.E., 2001, Comparison of flattened blastozoan echinoderms: Insights from the new early Ordovician eocrinoid Haimacystis rozhnovi: Journal of Paleontology, v. 75, p. 985-992.

Sumrall, C.D., Brett, C.E., Dexter, T.A., and Bartholomew, A., 2009, An enigmatic blastozoan echinoderm fauna from central Kentucky: Journal of Paleontology, v. 83, p. $739-749$.

Termier, H., and Termier, G. 1950, Contribution à l'étude des faunes paléozoïques de l'Algérie: Service de la Carte Géologique de l'Algérie, Bulletin, p. $1-83$.

Termier, H., and Termier, G. 1972, Sur les affinités des Herpetocystidés: Academie des Sciences de Paris, Compte Rendu, v. 274, p. 1645-1647.

Thoral, M., 1935, Contribution à la paléontologie de l'Ordovicien de la Montagne Noire et revision sommaire de la faune cambrienne de la Montagne Noire: Montpelier, $365 \mathrm{p}$.

Tillman, C.G., 1967, Triamara cutleri, a new cystoid from the Osgood Formation (Silurian) of Indiana: Journal of Paleontology, v. 41, p. 222-226.

Ubaghs, G., 1963, Rhopalocystis destombesi n.g., n. sp. Eocrinoïde de l'Ordovicien inférieur (Trémadocien supérieur) du Sud marocain: Notes du Service Géologique du Maroc, v. 23, p. 25-45.

Ubaghs, G., 1968, Eocrinoidea, in Moore, R.C., ed., Treatise on Invertebrate Paleontology, Part S, Echinodermata 1: Lawrence, Kansas, Geological Society of America and University of Kansas, p. S455-S495.

von Buch, L., 1840, Über Sphaeroniten und einige andere Geschlechter, aus welchen Crinoideen entstehen: Königlich Preussische Akademie der Wissenschaften zu Berlin, Verhandlungen, (1840), p. 56-60.

von Buch, L., 1846, Über Cystideen eingeleitet durch die Entwicklung der Eigenthumlichkeiten von Caryocrinites ornatus Say: Königlich Preussische Akademie der Wissenschaften zu Berlin, Verhandlungen, (for 1844), p. 89-116 (also published in English and French in the same year).

von Koenen, A., 1886, Ueber neue Cystideen aus den Caradoc-schichten der Gegend von Montpelier: Neues Jauhrbuch für Mineralogie, Geologie und Paläontologie, v. 2, p. 246-254.

Wahlenberg, G., 1821, Petrificata telluris svecanae examinata a Georgio Wahlenberg: Nova Acta Societatis Regiae Scientarum Upsaliensis, v. 3, p. $1-116$.

Walcott, C.D., 1917, Cambrian geology and paleontology IV, fauna of the Mount Whyte Formation: Smithsonian Miscellaneous Collections, v. 67, p. $61-114$.

White, C.A., 1876, Description of new species of fossils from the Palaeozoic rocks of Iowa: Proceedings of the Academy of Natural Sciences, Philadelphia, v. 28, p. 27-34.

Zamora, S., and Rahman, I.A., 2015, Deciphering the early evolution of echinoderms with Cambrian fossils: Palaeontology, v. 57, p. 1105-1119.

Zamora, S., and Smith, A.B., 2012, Cambrian stalked echinoderms show unexpected plasticity of arm construction: Royal Society London, Proceedings, v. B279, p. 293-298.

Zamora, S., Sumrall., C.D., Zhu, X.-J., and Lefebvre, B., in press, A new stemmed echinoderm from the Furongian of China and the origin of Glyptocystitida (Blastozoa, Echinodermata): Geological Magazine, CJO 2016, doi: 10.1017/S001675681600011X.

Zhao, Y.L., Sumrall, C.D., Parsley, R.L., and Peng, J. 2010, Kailidiscus, a new plesiomorphic edrioasteroid from the basal middle Cambrian Kaili Biota of Guizhou Province, China: Journal of Paleontology, v. 84, p. 668-680.

Accepted 18 October 2016 